Portland State University

PDXScholar

Civil and Environmental Engineering

Undergraduate Honors Theses

Spring 2021

\title{
The Critical Energy Infrastructure (CEI) Hub: A Look into the Seismic Fragility of Oregon's Fuel
}

Annecy Bal

Portland State University

Follow this and additional works at: https://pdxscholar.library.pdx.edu/cengin_honorstheses

Part of the Civil and Environmental Engineering Commons

Let us know how access to this document benefits you.

\section{Recommended Citation}

Bal, Annecy, "The Critical Energy Infrastructure (CEI) Hub: A Look into the Seismic Fragility of Oregon's Fuel" (2021). Civil and Environmental Engineering Undergraduate Honors Theses. 15.

https://doi.org/10.15760/honors.1144

This Thesis is brought to you for free and open access. It has been accepted for inclusion in Civil and Environmental Engineering Undergraduate Honors Theses by an authorized administrator of PDXScholar. Please contact us if we can make this document more accessible: pdxscholar@pdx.edu. 


\title{
THE CRITICAL ENERGY INFRASTRUCTURE (CEI) HUB:
}

A Look into the Seismic Fragility of Oregon's Fuel

Civil and Environmental Engineering Department Honors Thesis June 2021

\author{
By: Annecy Bal
} Faculty Advisor: Peter Dusicka, Ph.D 


\section{Contents}

Abstract .................................................................................. 2

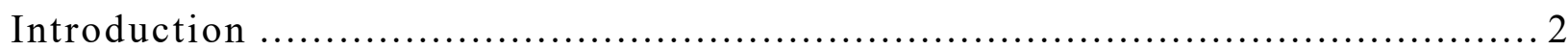

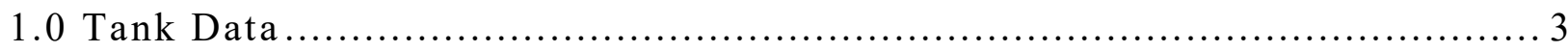

1.1 Capacity Criteria ......................................................... 3

1.2 Average Fill Inconsistencies .............................................. 4

1.3 Fuel Types................................................................ 4

2.0 Secondary Containments ................................................. 6

2.1 Secondary Containment Identification ................................... 7

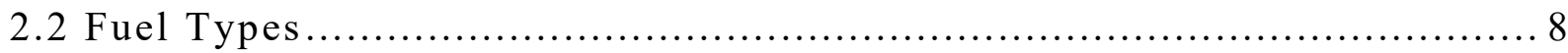

2.3 Tanks with Unknown Location ......................................... 9

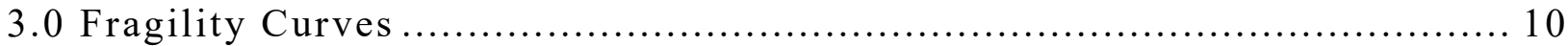

3.1 Fragility Curves ........................................................ 11

3.2 DS versus Risk State ................................................... 11

3.3 Effects of Percent Fill .................................................. 12

3.4 Effects of Anchorage ................................................ 14

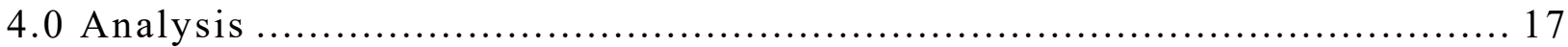

4.1 Peak Ground Acceleration................................................ 18

4.2 Unanchored Tanks ........................................................ 19

4.3 Percent Fill Amplification .............................................. 20

4.4 Expected Repercussions for CEI Hub................................... 22

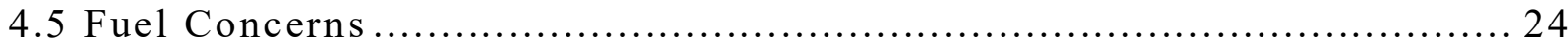

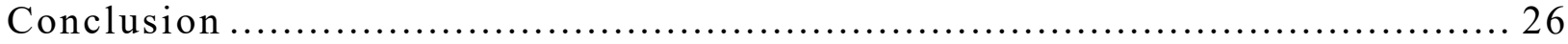

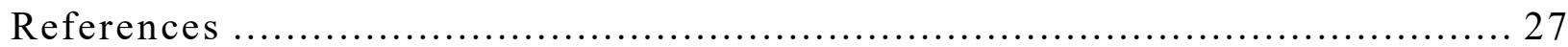

Appendix A - Secondary Containment....................................... 28

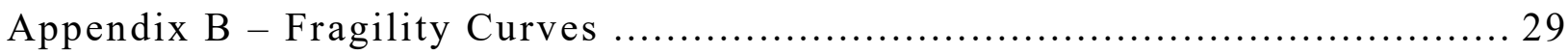

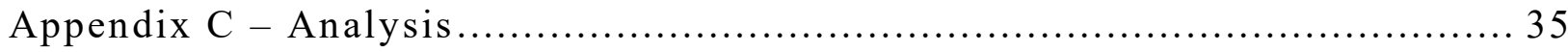




\section{Abstract}

This research evaluates the seismic vulnerability of the Critical Energy Infrastructure (CEI) Hub and the associated fuel repercussions for the expected 9.0 magnitude earthquake along the Cascadia Subduction Zone. The tanks in the CEI hub are analyzed based on size and content. The owners and secondary containment areas are discussed using the same parameters. Various analysis techniques are reviewed to determine the most appropriate seismic fragility estimate for the site. The seismic vulnerability is analyzed using fragility curves by Hazus, American Lifeline Alliance, and D'Amico. The fragility curves are applied to the CEI Hub to determine expected damage and the related fuel loss impacts. Gasoline and diesel have the highest expected damage with a maximum prediction of 13.7 million and 9.5 million gallons respectively experiencing complete content loss.

\section{Introduction}

The CEI Hub is located on the Willamette River in NW Portland, Oregon and is approximately 6 miles long. The CEI Hub accounts for the storage of $90 \%$ of Oregon's fuel and contains all jet fuel used at the Portland International Airport (Dusicka \& Norton, 2019). The research aims to evaluate the seismic vulnerability of individual tanks based on size and content. The tank owners in the CEI Hub are British Petroleum (BP), Chevron, Kinder Morgan, McCall, Nustar, Pacific Terminal Services, Phillips 66, Shell, and Zenith. Shell and Zenith do not currently have available information. 


\subsection{Tank Data}

The purpose of this section is to analyze and characterize the existing tanks in the CEI Hub. The research includes information on 514 tanks with geographical information for 271 tanks. The preliminary categorization of tanks aims to determine the volume and content held by the tanks.

\subsection{Capacity Criteria}

A 100,000 gallon capacity cut-off is employed so analysis focuses on larger tanks. There are 5 tanks in the data that did not have a documented capacity. Chevron and Nustar make up the tanks with 2 and 3 tanks respectively. 6 tanks had a documented capacity of 0 gallons, and all are owned by BP. Figure 1-1 shows the fuel distribution of the total CEI Hub with decreasing single tank capacities.

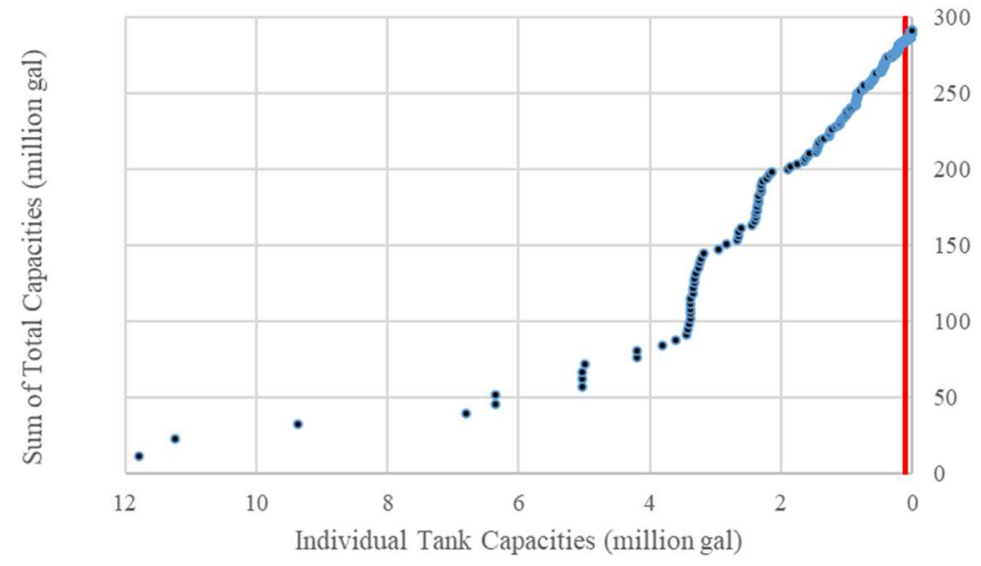

Figure 1-1 Sum of Total Tank Capacities by decreasing individual tank capacity (million gallons). Points represent individual tanks, and red line represents the 100,000 gallon capacity cut-off.

A majority of fuel is able to stay in analysis with the cutoff. Tanks with a capacity greater than 100,000 gallons make up approximately $98 \%$ of the total capacity of the data set. This accounts for approximately 285 million gallons for analysis. The cut-off reduces the number of tanks analyzed from 514 to 197 . In addition, of the 271 tanks with geographical information, 171 tanks 
had a capacity greater than 100,000 gallons. Only tanks with capacity greater than 100,000 gallons were used for the remainder of analysis.

\subsection{Average Fill Inconsistencies}

The tank capacity was used as the main input for the tanks due to uncertainty in the recorded average fill data. The average fill in 27 of the documented 514 tanks recorded greater than the capacity of the tank. An average fill greater than the capacity indicates an error in the record. A commonality in tanks with an average fill greater than the capacity could not be found. In addition, 255 tanks did not have a recorded average fill. Due to this, it was determined that average fill would not be used for analysis.

\subsection{Fuel Types}

The tanks were analyzed further based on fuel type. The purpose of this analysis is to determine the repercussions of lack of access to different types of fuel. Non-fuel includes substances like asphalt, lubricants, motor oil, waters, and base oils. Tanks with gasoline/diesel have a history and capability of holding both substances. Figure 1-2 shows the fuel distribution of the CEI Hub by volume.
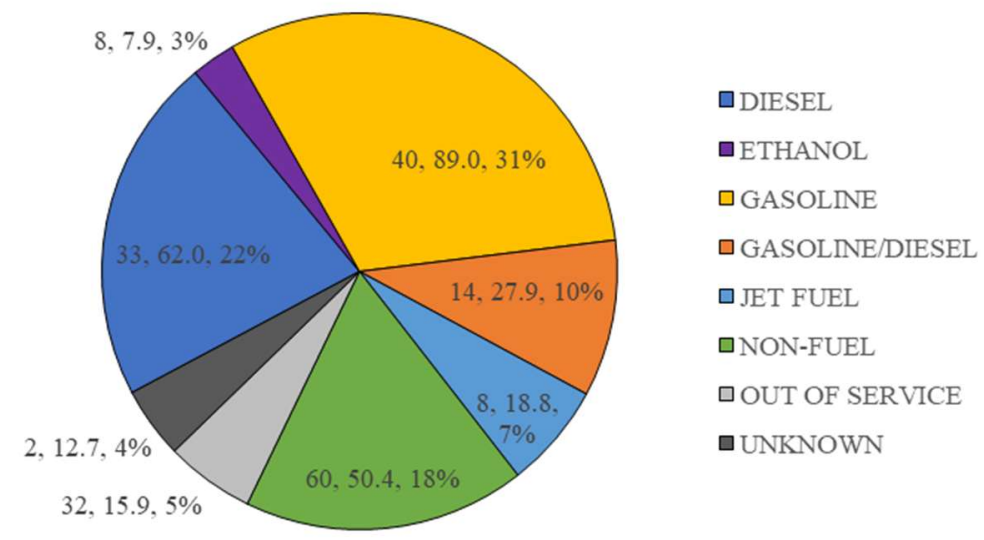

Figure 1-2 Fuel distribution of the CEI Hub by volume. 
The number of tanks, total capacity (million gallons), and percent of total capacity are shown in the above figure. The majority of fuel is gasoline (31\%) and diesel $(22 \%)$, equating to approximately 90 million gallons of gasoline and approximately 60 million gallons of diesel fuel. Gasoline is contained in 40 tanks, and diesel is contained in 33 tanks. Non-fuel accounts for the largest number of tanks at 61 tanks but only $18 \%$ of the total capacity of the CEI Hub. Two tanks with an unknown substance account for $4 \%$ of total capacity, and 32 out of service tanks account for $5 \%$. Ethanol represents $3 \%$ of the total capacity in 8 tanks. Jet fuel accounts for $7 \%$ of the total volume in 8 tanks. As seen, the number of tanks is not an indicator of total cumulative capacity, and due to this wide variability in tank size both number of tanks and total cumulative capacity are used for the majority of analysis. Figure 1-3 shows the fuel distribution based on owner.
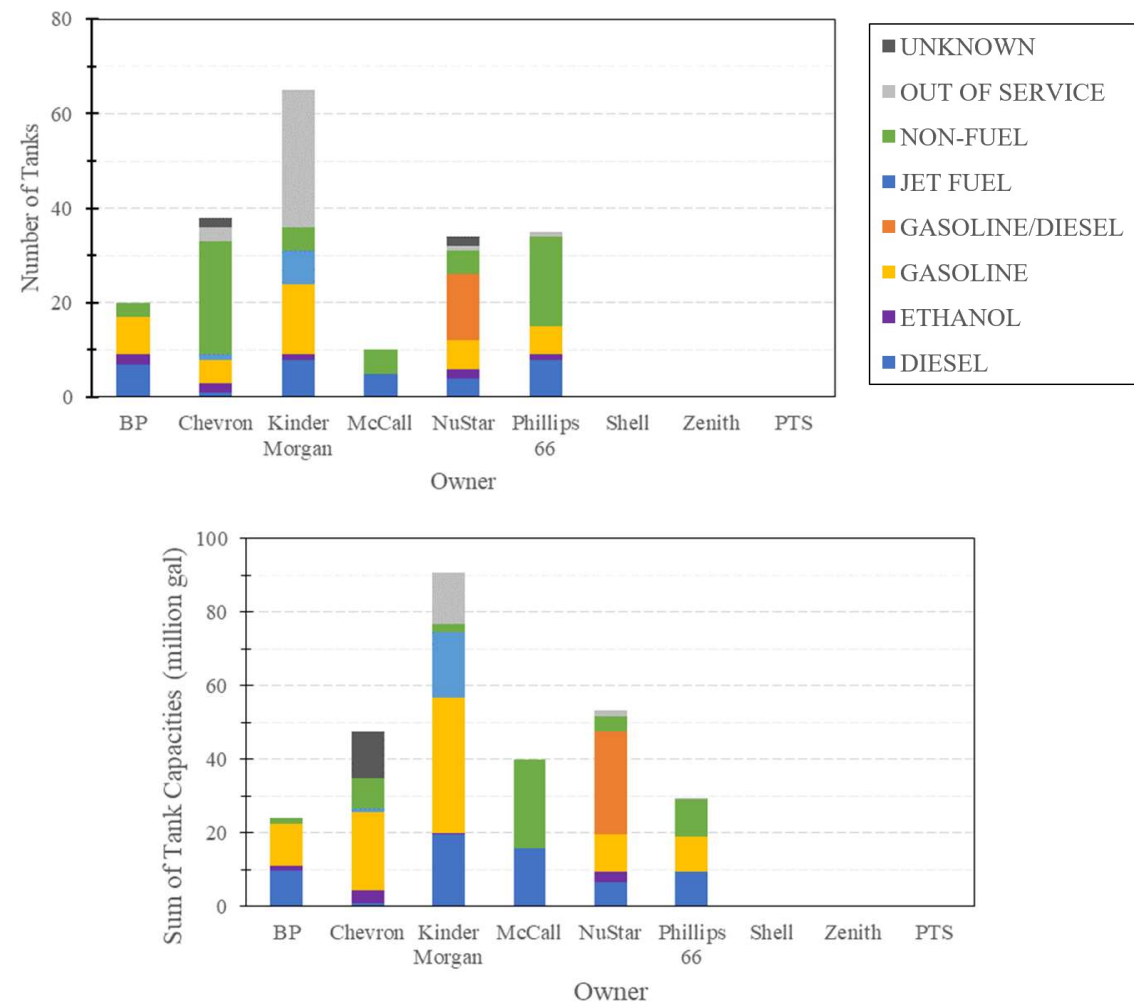

Figure 1-3 Fuel distribution by owner of the CEI Hub using number of tanks (Top) and sum of tank capacities (bottom). 
Kinder Morgan has the largest number of tanks and largest total capacity of 93 million gallons in 65 tanks. Notably, Kinder Morgan owns 29 out of service tanks that hold a total capacity of approximately 25 million gallons. Kinder Morgan holds approximately 37 million gallons of gasoline in 15 tanks and 20 million gallons of jet fuel in 7 tanks. Nustar has the second highest total capacity at 53 million gallons in 34 tanks, almost half that of Kinder Morgan. Nustar stores a majority of gasoline/diesel, approximately 28 million gallons. Chevron contains the 2 tanks with unknown substance and 24 non-fuel tanks holding a cumulative capacity of approximately 8 million gallons. Comparatively, McCall has 5 non-fuel tanks holding a cumulative capacity of 24 million gallons. The other 5 tanks owned by McCall contain 15.6 million gallons of diesel.

\subsection{Secondary Containments}

The tanks located in the CEI hub are surrounded by a secondary containment. Secondary containment acts as a second line of defense in the event of a tank failure. The minimum requirements for secondary containment are determined by The Environmental Protection Agency (EPA) in 40 CFC 112.8 and 40 CFC 112.7 of the Spill Prevention, Control, and Countermeasure (SPCC) Regulation. For the purpose of the tank research, the most relevant criteria is in 40 CFC 112.8 stating that the secondary containment area needs at minimum to be able to contain the full capacity of the largest tank in addition to the precipitation of a 24 hour 25-year storm (2021). In addition the containment must be completely impervious (2021). A majority of the secondary containment systems are considered to be earth walls. A strong consensus of the location, area of, and volume capacity of the secondary containment could not be determined without more information. The secondary containment information was gathered from satellite imaging of the CEI Hub from google image. Throughout analysis, the 100,000 gallon tank capacity cutoff discussed in Section 1 will be used. 


\subsection{Secondary Containment Identification}

The outline of the secondary containment areas is shown in Figure 2-1 and are color coded by owner. Each facility contains multiple secondary containment areas. The secondary containments are numbered and use an abbreviated version of the owner's name. Maps labelling the northern and southern containment areas can be found in Appendix A. Kinder Morgan is the only owner with two separate tank facilities. KM1 and KM2 make up the Southern Kinder Morgan Wellbridge, and KM3 and KM4 make up the

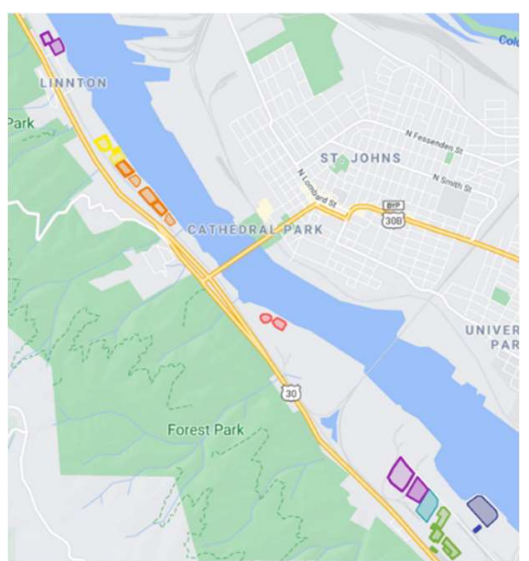

Figure 2-1 Secondary containment areas color coded by owner.

Northern Kinder Morgan Linton.

A table of the estimated area of the secondary containment can be found in Appendix A. Figure 2-2 graphs the secondary containment by area in acres.

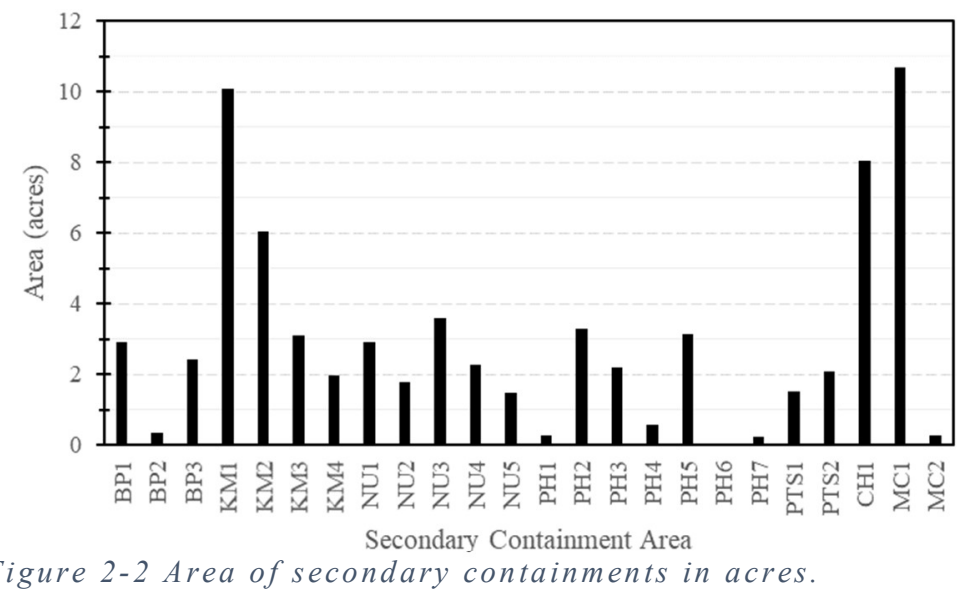

The largest secondary containments by area are MC1 and KM1 at 10.7 acres and 10.1 acres respectively. The smallest areas are PH6 and PH7 at 0.066 acres and 0.249 acres respectively. 


\subsection{Fuel Types}

The secondary containment areas were then analyzed based on fuel type. The criteria used in Section 1.0 continues to be employed for the analysis. Figure 23 shows the fuel distribution by secondary containment.
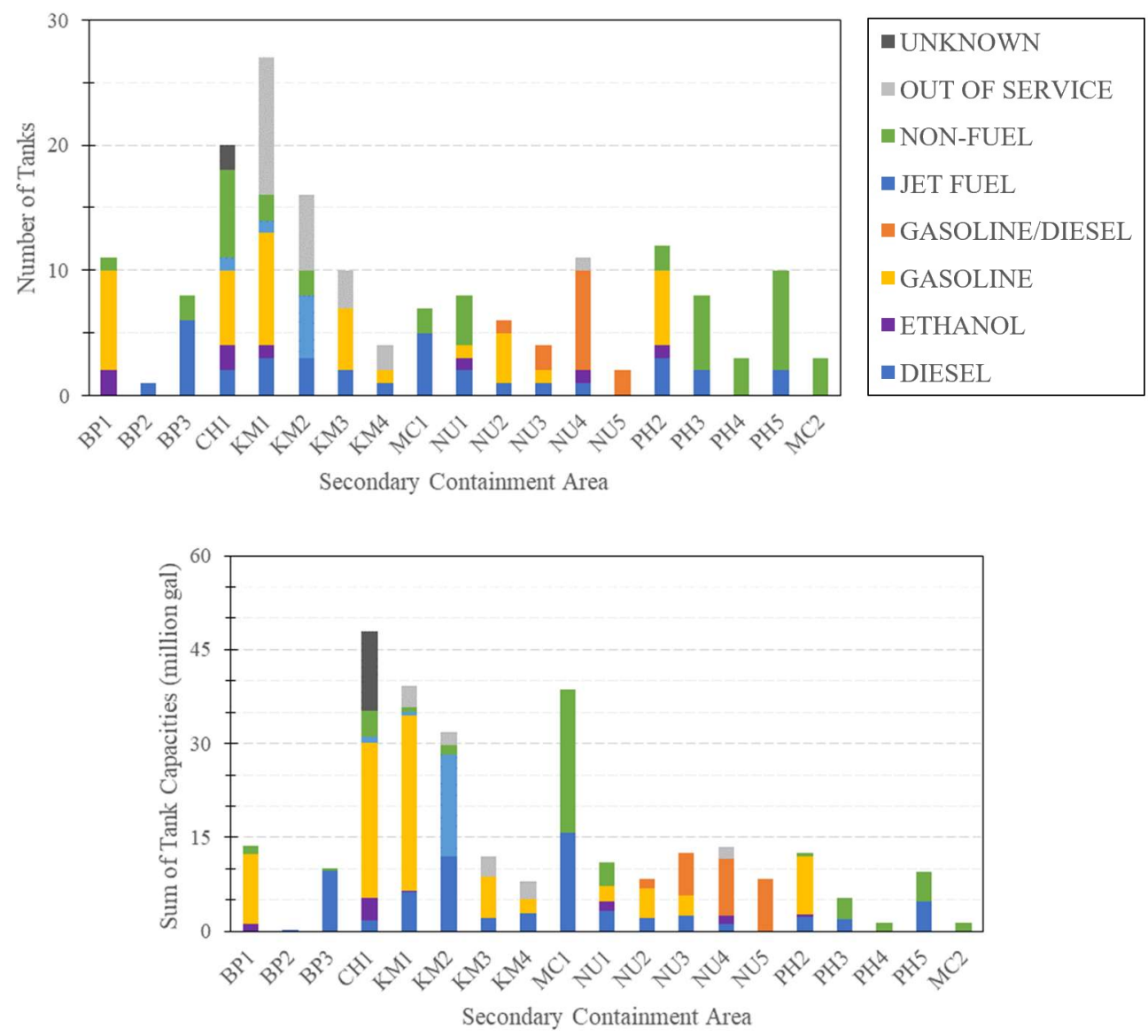

Figure 2-3 Fuel distribution by owner of secondary containment areas using number of tanks (Topt) and sum of tank capacities (Bottom).

$\mathrm{CH} 1, \mathrm{KM} 1$, and $\mathrm{MC} 1$ have the highest capacities at approximately 47.9 million, 39.2 million, and 38.7 million gallons respectively. KM1 and $\mathrm{CH} 1$ have the largest number with tanks of 27 and 20 tanks respectively. Comparatively, MC 1 contains only 7 tanks with a capacity greater than 100,000 gallons. KM1 contains a majority gasoline by volume, 28 million gallons, and contains 11 out 
of service tanks that hold 780 thousand gallons. CH1 holds 25 million gallons of gasoline in addition to approximately 13 million gallons of unknown substances. MC1 contains 23 million gallons of non-fuel, approximately 15 million gallons of diesel.

A primary concern is that there are large tanks grouped together in secondary containment areas. MC1 has two tanks with capacities greater than 10 million and 3 tanks with capacities greater than 1 million. $\mathrm{CH} 1$ has 1 tank with a capacity greater than 10 million, and 8 tanks with capacities greater than a million gallons. The minimum requirement for capacity of secondary containment areas is total capacity of the largest tank and precipitation; if only the minimum requirement is met for these $\mathrm{SC}$ areas, there would be a significant amount of substance going into the river if multiple large tanks failed.

\subsection{Tanks with Unknown Location}

There are 26 tanks with a capacity greater than 100,000 gallons that have an unknown location. Chevron, Kinder Morgan, and Phillips 66 own 19, 5, and 2 of the unknown tanks respectively. The unknown Kinder Morgan tanks are located in the Northern Linton Facility. This is known because the Tank IDs for all 5 tanks follow the convention of "KML\#\#\#\#". The substance was graphed for the unknown tanks in Figure 2-4. 

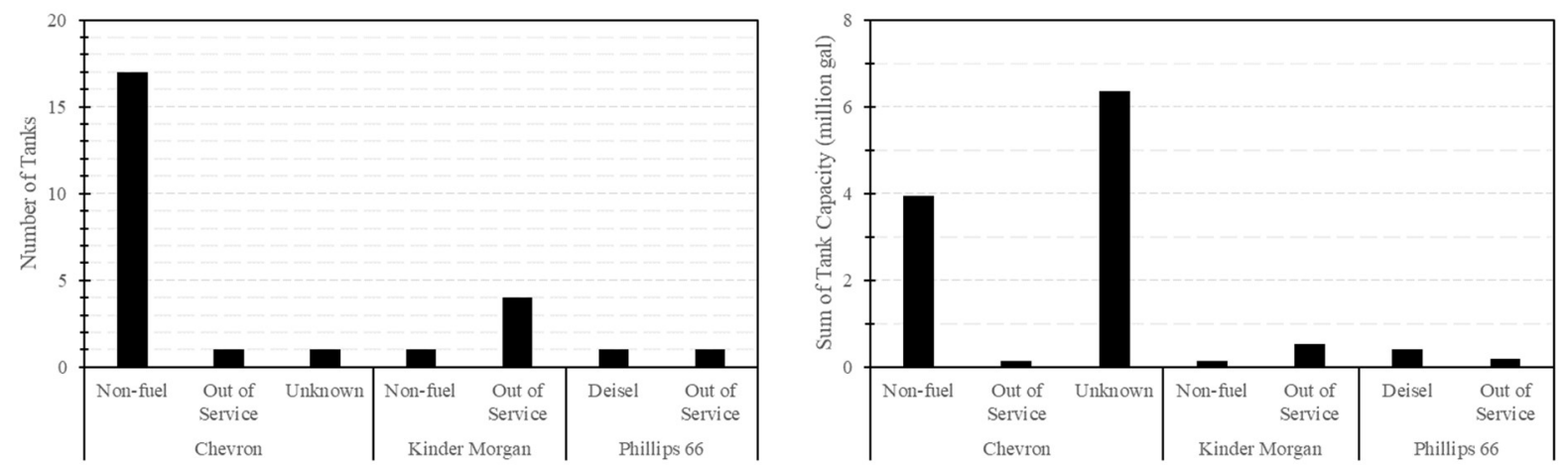

Figure 2-4 Fuel distribution of tanks with unknown secondary containment areas are shown using the number of tanks (Left) and sum of tank capacities (Right).

The 26 tanks hold a sum capacity of approximately 12 million gallons. Chevron holds 10.4 million gallons. Kinder Morgan holds approximately 660 thousand gallons. Phillips 66 holds approximately 600 thousand gallons. Notably, Chevron has one tank that holds 6 million gallons of unknown substance. The majority of the current analysis will be done in terms of the entire CEI Hub because uncertainty in the secondary containment areas due to both unknown tanks and secondary containment boundaries and volume capacities.

\subsection{Fragility Curves}

This section provides background information on available seismic fragility curves. Fragility curves are used to determine the possible repercussions of a seismic event for various Peak Ground Accelerations (PGA), and are commonly represented as lognormal functions. PGA refers to the highest acceleration of the ground during a seismic event and is recorded in terms of gravitational acceleration. Five fragility curves are considered to determine the most accurate estimates for the CEI Hub. Throughout this section, the different fragility curves and associated parameters are discussed prior to the further calculations detailed in Section 5.0. 


\subsection{Fragility Curves}

Five analysis techniques were considered, Hazus, American Lifeline Alliance (ALA), O’Rourke, Salzano, and D'Amico. ALA, O'Rourke, and Salzano use an empirical approach, and Hazus and D'Amico use an analytical approach (D'Amico \& Buratti, 2018). The different parameters used for the fragility curves are available in Table 3-1.

Table 3-1 Descriptions of the considered fragility curves. If the description applies the fragility curve, it is marked with an "X"(D'Amico \& Buratti, 2018).

\begin{tabular}{|l|c|c|c|c|c|c|c|c|}
\hline \multirow{2}{*}{$\begin{array}{c}\text { Fragility } \\
\text { Curve }\end{array}$} & \multicolumn{4}{|c|}{ Parameters } & \multicolumn{2}{c|}{ Analysis Type } & \multicolumn{2}{c|}{ Definitions } \\
\cline { 2 - 9 } & All tanks & $\begin{array}{l}\text { Unanchored } \\
\text { Tanks }\end{array}$ & H/D & \%Fill & Empirical & Analytical & Damage State & Risk State \\
\hline Hazus & & $\mathrm{X}$ & & & & $\mathrm{X}$ & $\mathrm{X}$ & \\
\hline ALA & $\mathrm{X}$ & $\mathrm{X}$ & & $\mathrm{X}$ & $\mathrm{X}$ & & $\mathrm{X}$ & \\
\hline O'Rourke & $\mathrm{X}$ & & $\mathrm{X}$ & $\mathrm{X}$ & $\mathrm{X}$ & & $\mathrm{X}$ & \\
\hline D'Amico & $\mathrm{X}$ & $\mathrm{X}$ & $\mathrm{X}$ & $\mathrm{X}$ & & $\mathrm{X}$ & $\mathrm{X}$ & $\mathrm{X}$ \\
\hline Salzano & $\mathrm{X}$ & $\mathrm{X}$ & & $\mathrm{X}$ & $\mathrm{X}$ & & & $\mathrm{X}$ \\
\hline
\end{tabular}

Percent fill and anchorage conditions were determined as the focus for the damage parameters. The H/D parameter refers to the height of the tank divided by the diameter of the tank. Currently, there are 25 tanks with an unknown height and diameter, and the known height to diameter ratios of tanks is highly variable. Due to this H/D is not used for analysis. The anchorage conditions have a significant effect on the damage probability of tanks. This comparison is investigated in Section 3.4. In addition, the tanks in the CEI Hub are assumed to be at a high fill, and therefore the effect fill level is discussed in Section 3.3. The difference in Risk State and Damage State are discussed in Section 3.2.

\subsection{DS versus Risk State}

The two main definitions used to assess seismic vulnerability are Risk State (RS) and Damage State (DS). RS emphasizes the loss of content and environmental consequences. DS focuses on the structural damage of the tanks (D'Amico \& Buratti, 2018). Different analysis techniques 
employ various definitions for RS and DS. Only fragility curves that use DS are considered for analysis to allow for comparison to Hazus. Hazus is the methodology generated by the Federal Emergency Management Agency (FEMA), and therefore can be considered a baseline for other analysis. The definition of DS is not consistent for the various curves. It was determined that the variation in DS definition was insignificant, so differences were excluded from the analysis to allow for simplicity. A basic definition of damage states is provided in Table 3-2.

Table 3-2 DS conceptual definitions.

\begin{tabular}{|c|c|}
\hline Damage State & \multicolumn{1}{|c|}{ Defintion } \\
\hline DS 3 & Moderate Damage, Minor Content Loss \\
\hline DS 4 & Extensive Damage, Moderate Content Loss \\
\hline DS 5 & Complete Damage, Complete Content Loss \\
\hline
\end{tabular}

In addition to Hazus, ALA and D'Amico are used for analysis because both analyze the effects of anchorage conditions and percent fill and use DS definitions. The mean, $\mu$, and the standard deviation, $\sigma$, of $\ln (\mathrm{PGA})$ for each damage state for Hazus, ALA, and D'Amico are recorded in Appendix B Tables B-1, B-2, and B-3, respectively. For the fragility curve discussion, only DS 4 graphs are shown unless otherwise indicated. DS 3 and DS 5 fragility curves can be found in Appendix B.

\subsection{Effects of Percent Fill}

The effect of percent fill for tanks was analyzed in D'Amico and ALA. The fragility curves show similar effects for percent fill. The variation due to percent fill for D'Amico and ALA are shown in Figure 3-1. 
ALA

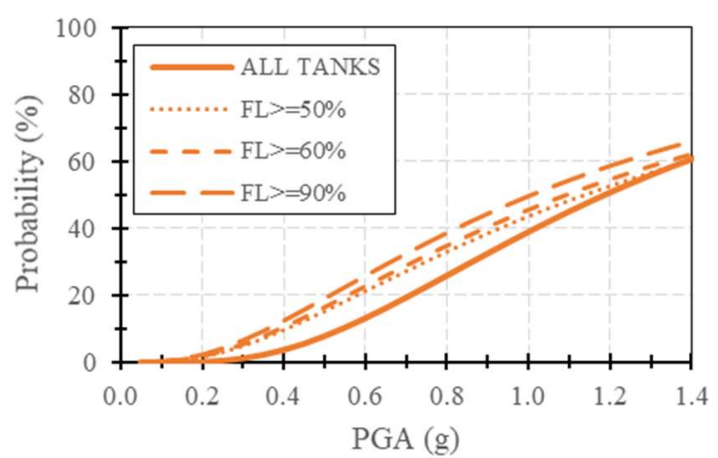

D'Amico

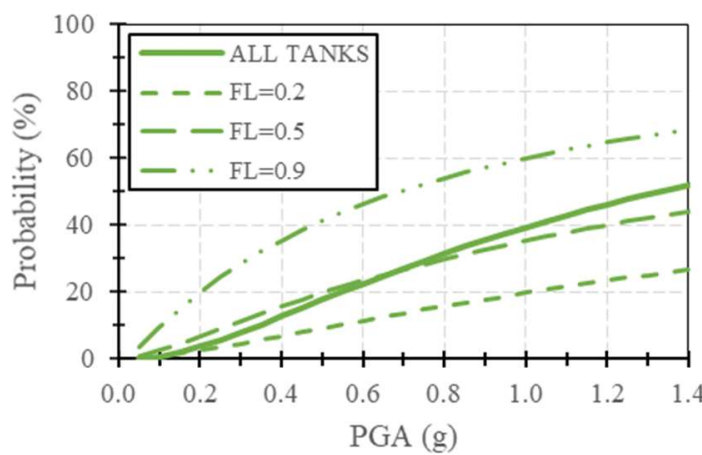

Figure 3-1 DS 4 fragility curves for the effects of percent fill. ALA is shown on the left, and D'Amico is shown on the right.

Both D'Amico and ALA show that the seismic vulnerability for tanks increases with an increase in fill. ALA is an empirical methodology which is why it uses tank data with fill percentages at greater than or equal to a percent. On the other hand, D'Amico is an analytical technique that inputs the fill value of $0.2,0.5$, and 0.9 which equates to $20 \%, 50 \%$, and $90 \%$ fill. D'Amico uses percent fill as an input that affects the tank fragility which is why all tank data is most similar to 0.5 fill. ALA shows that all tank data is less than tanks with a fill greater than or equal to $50 \%$. This is because ALA used tanks that had a fill less than $50 \%$ in the all tank data. These trends are similar for DS 3 and DS 5 for D'Amico and DS 3 for ALA. For DS 5, ALA shows a significant change in trend. Figure 3-2 shows ALA's DS 5 fragility curve for affect of percent fill. 


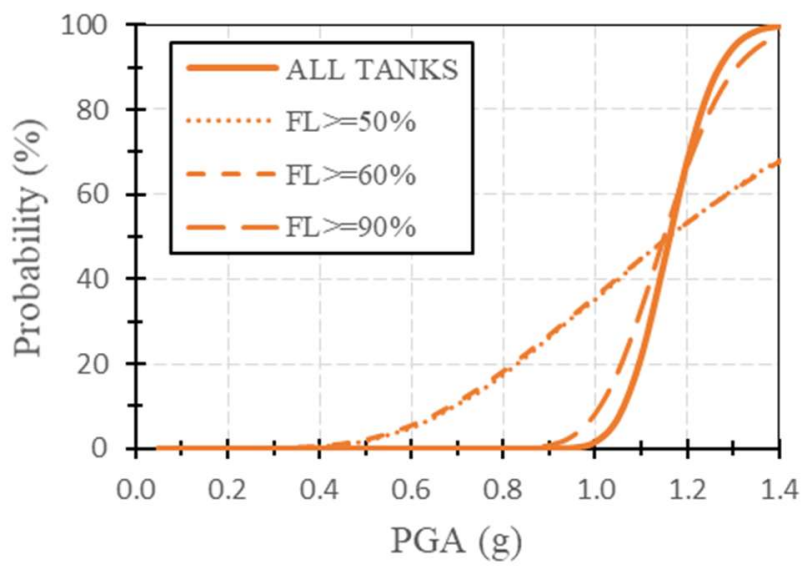

Figure 3-2 ALA's DS 5 graph depicting the effects of percent fill.

Tanks will fill greater than or equal to $50 \%$ and $60 \%$ show a similar fragility, and all tanks and tanks with fill greater than or equal to $90 \%$ show a similar fragility. Tanks greater than $50 \%$ and greater than $60 \%$ fill have a significantly higher probability of damage than tanks greater than $90 \%$ fill for PGA values $0.4 \mathrm{~g}-1.0 \mathrm{~g}$. ALA cites the small data set for the variation caused in DS 5. For tanks that have fill greater than or equal to $50 \%$, only 15 tanks sustained DS 5 damage out of the total database of 251 tanks. ALA considers that $6 \%$ of tanks that reach DS 2 DS could be a more accurate estimate (2001). For the current analysis, the ALA fragility function is used for DS 5 data, though there are significant uncertainties.

\subsection{Effects of Anchorage}

Hazus, D'Amico, and ALA provide fragility curves for only unanchored tanks. Figure 3-3 compares the difference in damage probability for all tank data versus unanchored tanks. 


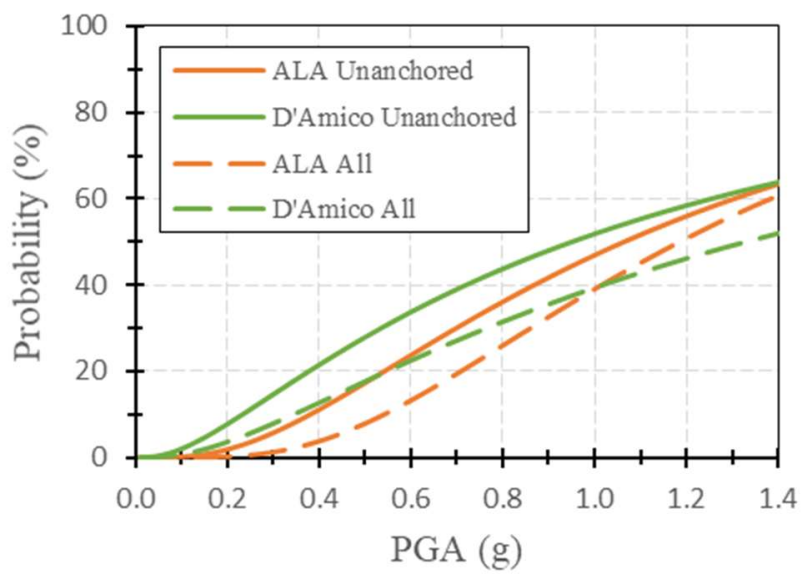

Figure 3-3 DS 4 fragility curves for ALA and D'Amico unanchored versus all tank.

ALA and D'Amico both show that probability of damage for unanchored tanks is higher than the all tank fragility curve. Hazus only provides fragility curves for unanchored and anchored tanks, and therefore an all tank fragility curve cannot be compared. Figure 3-4 compares unanchored and anchored tank fragility for Hazus.

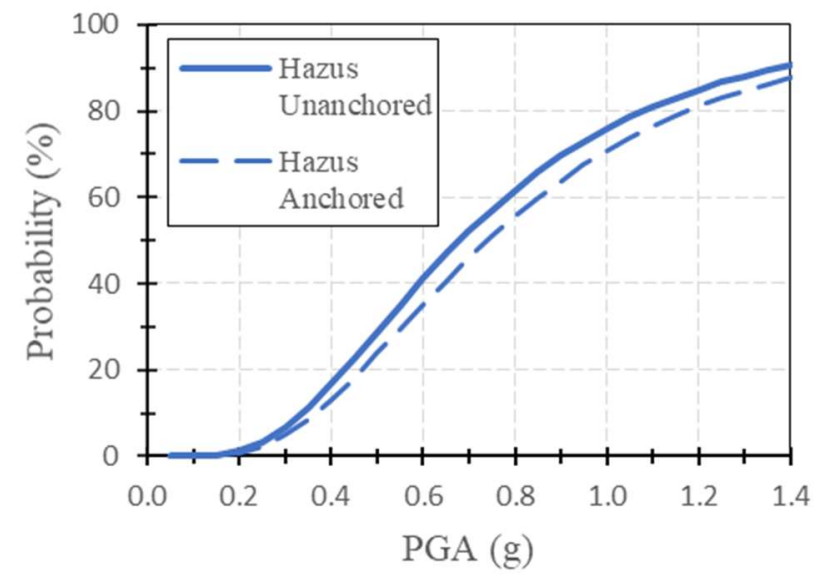

Figure 3-4 DS 4 fragility curve for Hazus unanchored versus anchored tanks.

Similar to ALA and D'Amico, Hazus shows a higher probability of damage for unanchored tanks. The difference in unanchored tanks and anchored tanks for Hazus is smaller than ALA and D’Amico. Figure 3-5 compares Hazus, D’Amico, and ALA unanchored fragility curves. 


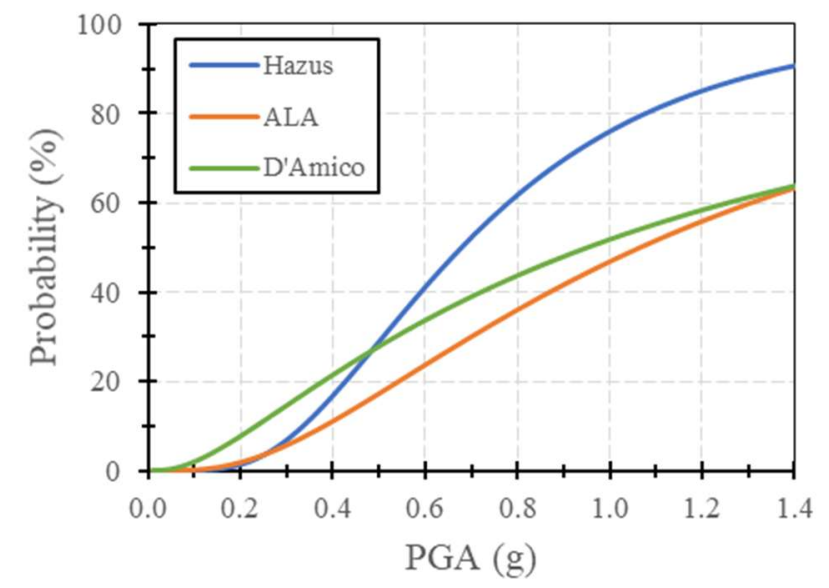

Figure 3-5 DS 4 fragility curves for Hazus, ALA, and $D^{\prime}$ Amico unanchored tanks.

The fragility curves produce similar information for low PGA values. D'Amico and ALA

provide similar values for large PGA values, and Hazus shows significantly higher probability of failure for PGA values higher than $0.6 \mathrm{~g}$.

In addition to Hazus, ALA produces a fragility curve for anchored tanks. Figure 3-6 compares ALA anchored tanks to all tanks.

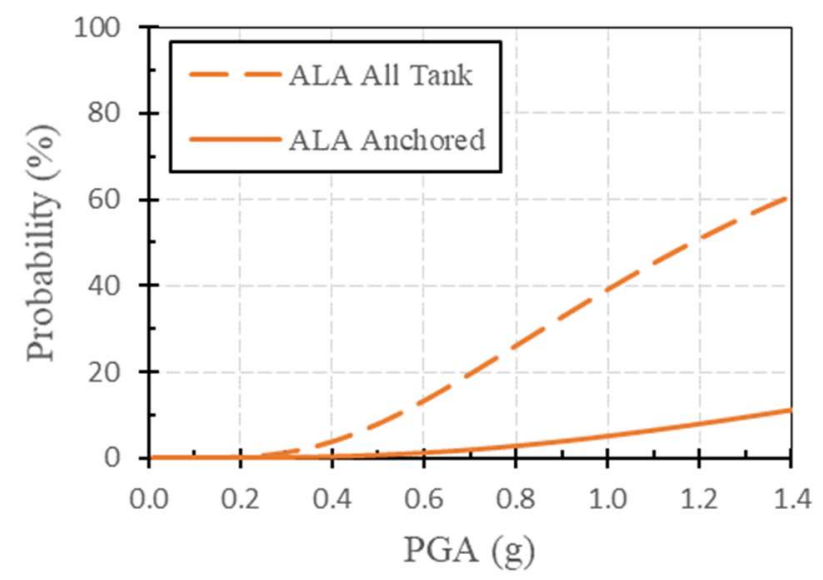

Figure 3-6 DS 4 fragility curve for ALA anchored versus all tank. 
For ALA, anchored tanks have a significantly lower probability of failure compared to all tanks for PGA values greater than $0.2 \mathrm{~g}$ for DS 4. For PGA values lower than $0.2 \mathrm{~g}$, the probability of DS 4 is nominal for both anchored tanks and all tanks. Figure 3-7 compares Hazus and ALA.

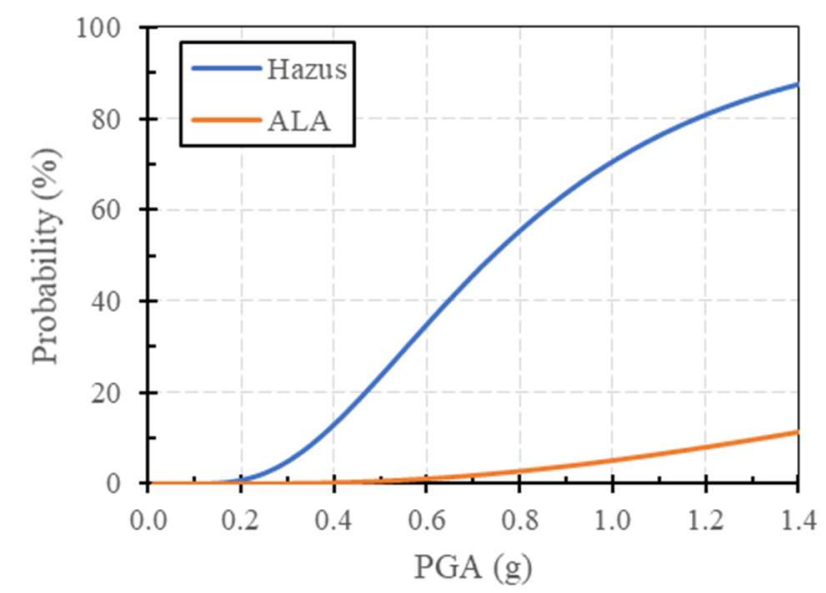

Figure 3-7 DS 4 graph for Hazus and ALA anchored tanks.

Hazus and ALA have significantly different probabilities of failure after $0.2 \mathrm{~g}$ for all DSs. Hazus predicts higher probability of damage, however ALA predicts probability of damage less than $20 \%$ for PGA values up to $1.4 \mathrm{~g}$.

\subsection{Analysis}

The analysis combines the fragility curves discussed in Section 3 with tank information from Section 3 using anticipated PGA values for the site. The analysis consists of multiple estimations to show the range of probable damage. The CEI Hub is analyzed globally then by fuel type. 


\subsection{Peak Ground Acceleration}

Due to geology and wave propagation, the exact impact of a 9.0 magnitude earthquake cannot be defined. Instead, different scenarios for the expected 9.0 magnitude were determined by the CSZ@pdx tool (Dusicka). Figure 4-1 shows the 30 different seismic scenarios.

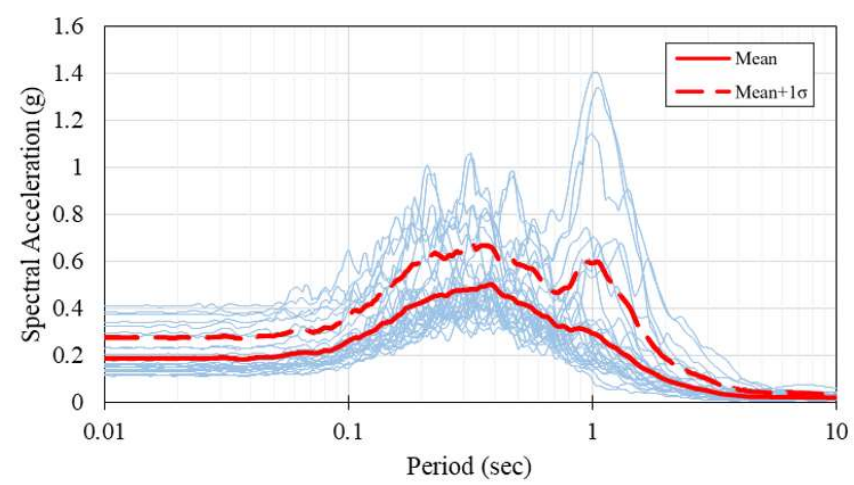

Figure 4-1 Graph of spectral acceleration by period for 30 possible seismic events and the mean and mean plus one standard deviation predicted values.

The grey lines were used to plot 30 different seismic event scenarios, and the red lines plotted show the mean and mean plus one standard deviation. The seismic event scenarios are site specific and take into account the geography and geology of the CEI Hub. The spectral acceleration represents the acceleration of a point on a structure due to a seismic event and is dependent on the period of a structure. The PGA value occurs at period approaching 0 seconds. The mean PGA value is $0.187 \mathrm{~g}$, and the mean plus one standard deviation PGA value is $0.275 \mathrm{~g}$. Predicted PGA is inputted into the fragility curve lognormal function to provide a probability of damage. A majority of analysis is discussed in terms of the mean plus one standard deviation to create a conservative estimate. 


\subsection{Unanchored Tanks}

The anchorage conditions of tanks in the CEI Hub are currently unknown. To provide a conservative estimate of damage, all tanks are considered to be unanchored for the purpose of calculations. Figure 4-2 shows the probability of DS 4 Unanchored Tanks for PGA values of $0.187 \mathrm{~g}$ and $0.275 \mathrm{~g}$.

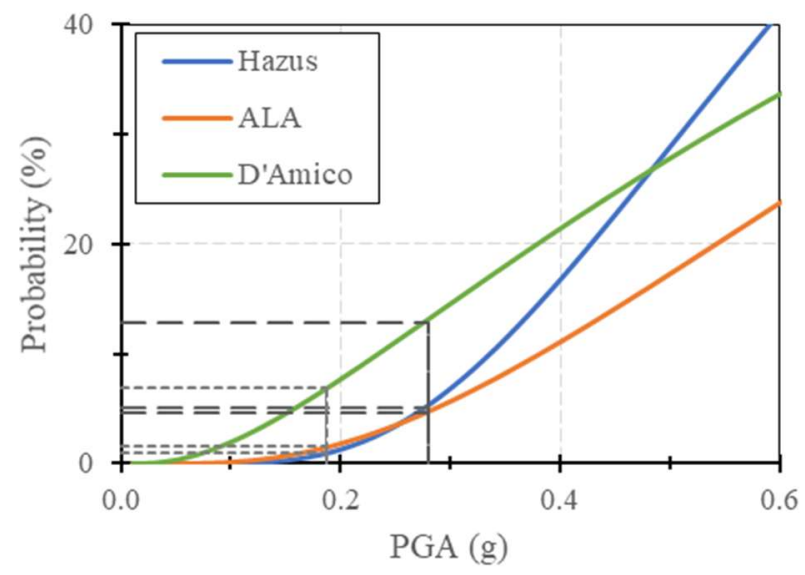

Figure 4-2 The probability of damage associated with $P G A$ values $0.187 \mathrm{~g}$ and $0.275 \mathrm{~g}$ for Hazus, $A L A$, and $D^{\prime}$ Amico unanchored tanks DS 4.

D'Amico provides the highest probability of DS 4 damage at $14 \%$ and $24 \%$ for PGA values $0.187 \mathrm{~g}$ and $0.275 \mathrm{~g}$ respectively. Comparatively, Hazus estimated $0.95 \%$ and $5.0 \%$ probability of DS 4 damage, and ALA estimated $1.5 \%$ and $4.6 \%$ probability of DS 4 damage. The difference in probability of failure from $0.187 \mathrm{~g}$ and $0.275 \mathrm{~g}$ decreases with higher DSs for all fragility curves. The average difference in probability of damage from $0.187 \mathrm{~g}$ to $0.275 \mathrm{~g}$ for each DS is comparable between each fragility curve. Hazus, ALA, and D'Amico have an average difference in probability of damage of $4.9 \%, 4.0 \%$, and $5.4 \%$ respectively. Hazus shows a small change in probability of damage for the PGA 
range for anchored versus unanchored, while D'Amico and ALA show a larger change for all tanks versus unanchored tanks.

\subsection{Percent Fill Amplification}

The expected damage for tanks with a high percent fill is greater than average tank data. To provide a conservative estimate of the probability of damage, the percent fill parameters of ALA and D'Amico are used to scale the unanchored tank probability. Figure 4-3 shows the probability of damage for ALA and D'Amico based on percent fill.

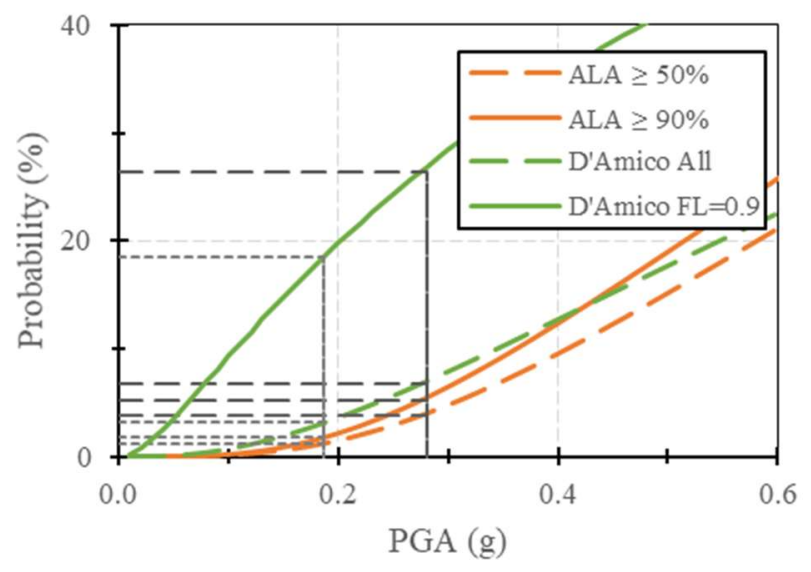

Figure 4-3 The probability of DS 4 damage associated with $P G A$ values $0.187 \mathrm{~g}$ and $0.275 \mathrm{~g}$ for different fill levels according to ALA and D'Amico.

For D'Amico, the unanchored tank data contains all fill levels, and for ALA unanchored tanks contain fill levels greater than or equal to $50 \%$. The difference between probability of failure for $90 \%$ fill and fill level used for unanchored tank analysis are determined at the mean and mean plus one standard deviation PGA values. 
The value is added to the unanchored tank data at the corresponding PGA value and DS. The objective is that the percent difference in probability of failure is comparable between all tank data and unanchored tanks. Figure 4-4 compares the unanchored tank fragility to the scaled value.

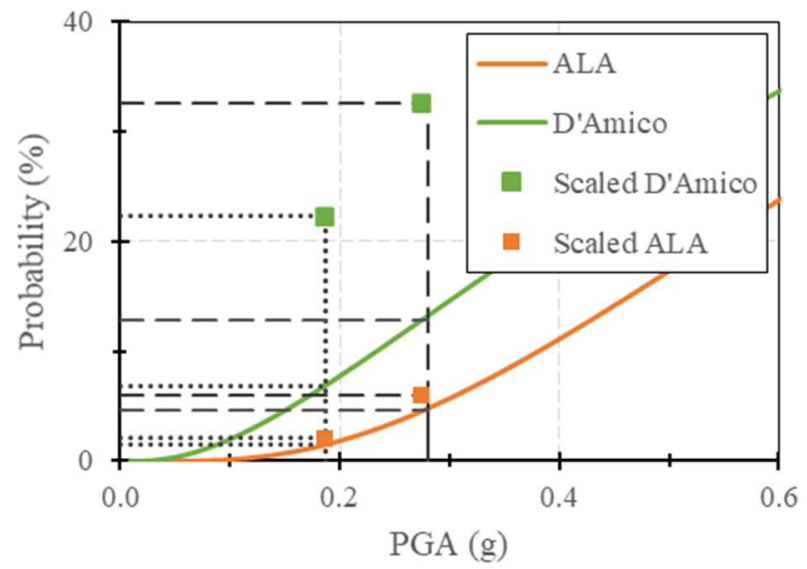

Figure 4-4 DS 4 probability of damage for ALA and $D^{\prime} A m i c o$ versus ALA Scaled and D'Amico Scaled.

The objective of this analysis is for the new fragility probability will simulate high filled unanchored tanks. Table 4-1 contains the calculated difference in probability of damage for the respective percent fills.

Table 4-1 The difference in 90\%
fill and percent fill used in
unanchored tank analysis for ALA
and D'Amico.
\begin{tabular}{|l|c|c|}
\hline Parameter & $\mu$ & $\mu+\sigma$ \\
\hline PGA (g) & 0.187 & 0.275 \\
\hline \multicolumn{3}{|c|}{ DS 3 } \\
\hline ALA Difference & 1.148 & 2.264 \\
\hline D'Amico Difference & 24.936 & 32.037 \\
\hline \multicolumn{3}{|c|}{ DS 4 } \\
\hline ALA Difference & 0.554 & 1.410 \\
\hline D'Amico Difference & 15.433 & 19.715 \\
\hline \multicolumn{3}{|c|}{ DS 5 } \\
\hline ALA Difference & - & - \\
\hline D'Amico Difference & 9.934 & 12.528 \\
\hline
\end{tabular}


As discussed in the Fragility Curve section, for DS 5 ALA provides a 90\% fill curve that is less than the $50 \%$ fill curve for PGA values less than $1.15 \mathrm{~g}$, so there are no changes to ALA's DS 5. For all DS and PGA values, D'Amico provides a higher difference in probability values than ALA. This is expected since D'Amico's percent fill fragility curve shows a more drastic difference as discussed in Section 3.3. The affects of percent fill cause a significant change in D'Amico, up to $32 \%$ for DS 3 . The change is less drastic for ALA, up to a maximum of $2.3 \%$.

\subsection{Expected Repercussions for CEI Hub}

The probability of damage for tanks with capacity greater than 100,000 gallons was determined for each fragility probability. The terminology "affected by" is used to describe tanks or total gallons that would experience a damage level. Figure 4-5 shows the expected damage for number of tanks out of the 197 tanks for a PGA value of $0.275 \mathrm{~g}$. Figure $\mathrm{C}-1$ graphs the expected damage for a PGA value of 0.187 in Appendix C.

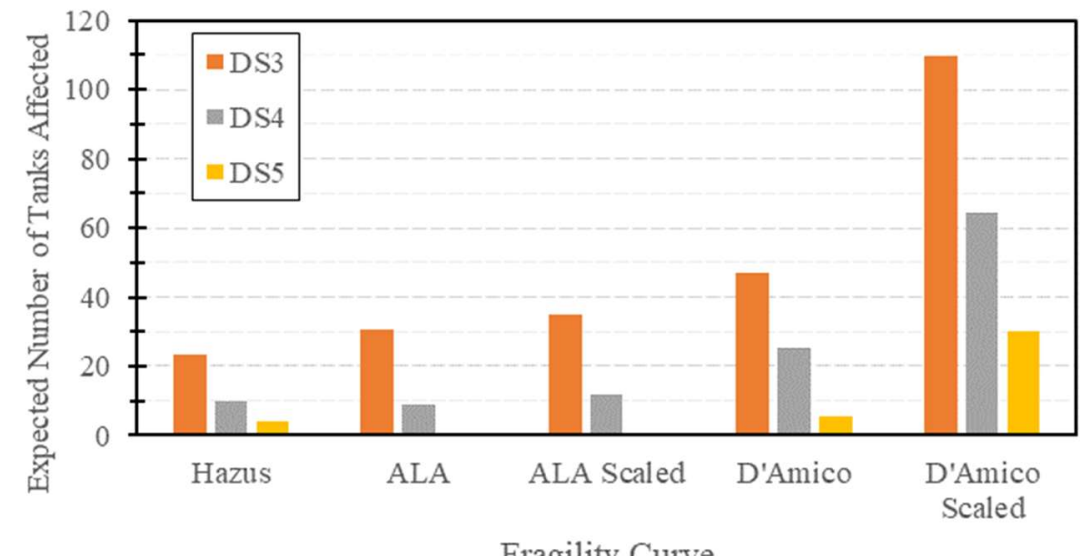

Fragility Curve

Figure 4-5 Expected number of tanks to experience damage by a $0.275 \mathrm{~g}$ $P G A$ value. 
D'Amico Scaled provides the highest estimate with approximately 110,64 , and 30 tanks for DS 3, 4, and 5 respectively. With the exception of DS 5, Hazus provides the lowest estimate with approximately 23,9 , and 4 tanks at DS 3,4 , and 5 respectively. For analysis purposes, the DS 5 parameters for ALA and ALA Scaled are considered uncertain due to concerns discussed in Section 3.3. The probability for damage and expected repercussions are recorded in Table C1 for both PGA values of $0.187 \mathrm{~g}$ and $0.275 \mathrm{~g}$. As expected, the predicted damage due to a $0.275 \mathrm{~g}$ PGA value is significantly higher than $0.187 \mathrm{~g}$.

The estimated gallons of substance that would experience different DS was determined by multiplying the number of total gallons and the probability of damage. Figure 4-6 shows the affected gallons for the PGA value of $0.275 \mathrm{~g}$. The expected affected gallons for a PGA value of $0.187 \mathrm{~g}$ are in Appendix D.

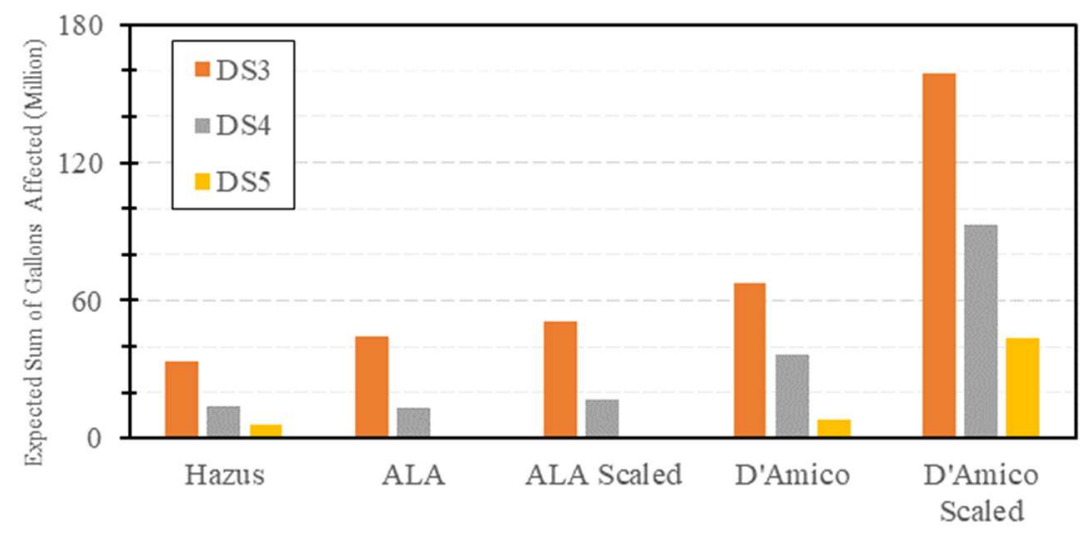

Fragility Curve

Figure 4-6 Expected gallons to be affected by a $0.275 \mathrm{~g}$ PGA value.

D'Amico Scaled predicts the highest damage at 158.9 million, 92.7 million, and 43.7 million gallons to experience DS 3,4 , and 5 damage respectively. Comparatively, D'Amico predicts 67.7 million, 36.6 million, and 8.08 million gallons for DS 3, 4, and 5 respectively. The D'Amico Scaled prediction is 2.4, 
2.5, and 5.4 times larger than the D'Amico prediction for DS 3, 4, and 5 respectively. Hazus provides the low prediction of 33.5 million, 14.3 million, and 5.9 million gallons to experience DS 3, 4, and 5 damage respectively.

\subsection{Fuel Concerns}

The fuel repercussions are analyzed through Hazus and D'Amico Scaled to provide the range of probability. The fuel is analyzed in terms of gallons, and both D'Amico Scaled and Hazus are discussed using the mean plus one standard deviation value of $0.275 \mathrm{~g}$. Figure $4-7$ shows the damage associated with Hazus.

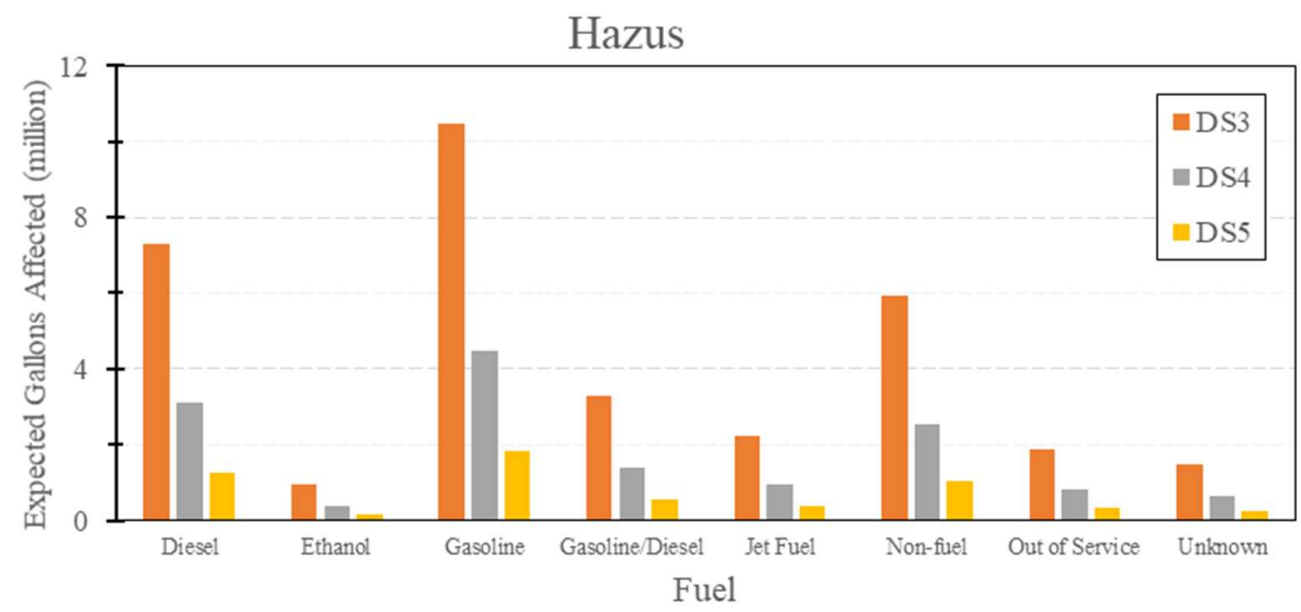

Figure 4-7 Fuel distribution of expected gallons to be affected by a $0.275 \mathrm{~g}$ PGA value.

As discussed in Section 1, the largest quantity of fuel is Gasoline and Diesel. According to Hazus, gasoline is expected to have approximately 10.5 million, 4.5 million, and 1.8 million gallons affected by DS 3, 4, and 5 respectively for a PGA value of $0.275 \mathrm{~g}$. Diesel is expected to have approximately 7.3 million, 3.1 million, and 1.3 gallons affected by DS 3, 4, and 5 respectively. Jet fuel is predicted to have 2.2 million, 942 thousand gallons, and 386 thousand gallons to 
be affected by DS 3, 4, and 5 respectively. Figure 4-8 shows estimated effects using D'Amico Scaled.

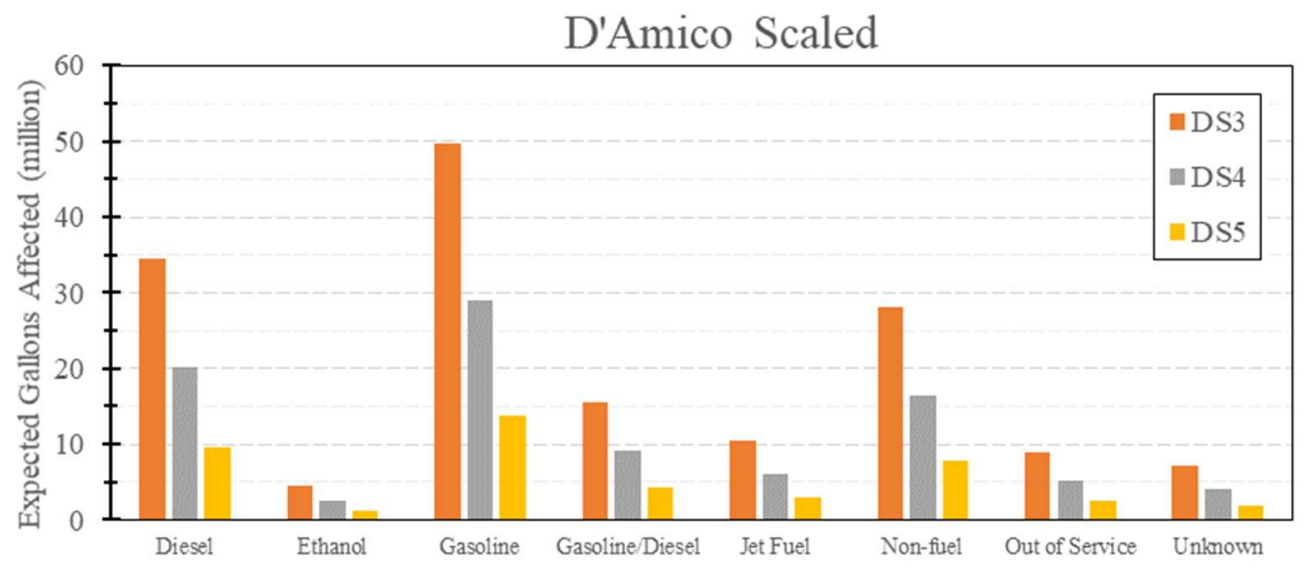

Figure 4-8 Fuel distribution of expected gallons to be affected by a $0.275 \mathrm{~g}$ PGA value

D'Amico Scaled provides a significantly larger estimation. For gasoline, the predicted effects are approximately 49.7 million, 29 million, and 13.7 million for DS 3, 4, and 5 respectively. This trend is similar for Diesel, which provides a prediction of 34.6 million, 20.2 million, and 9.5 million gallons affected by DS 3, 4, and 5 respectively. Jet fuel is predicted to have 10.5 million, 6.1 million, and 2.9 million gallons affected for DS 3, 4, and 5 respectively. Table C-2 in Appendix C provides the expected damage for Hazus, ALA, D'Amico, ALA Scaled, and D'Amico Scaled for the mean and mean plus one standard deviation PGA values.

For context, Oregon in 2017 used on average 4.45 million gallons of gasoline and ethanol (2019 Fuel Supply Forecast 2019). The loss from the D'Amico Scaled prediction for gasoline and ethanol DS 5 combined is 10.7 million gallons. This equates to the amount used by all of Oregon in approximately two and a half days. In 2017, Oregon used on average 2.05 million gallons of diesel 
per day (2019 Fuel Supply Forecast 2019). The loss due to DS 5 damage from the D'Amico Scaled prediction is equivalent to the diesel used by the entirety of Oregon in four and a half days. This prediction does not take into consideration loss of content due to DS 4 or DS 5. The low prediction from the Hazus DS 5 is equivalent to the diesel used in over half a day by the entirety of Oregon. This does not take into account loss due to DS 3 and DS 4. These comparisons are to create context for the amount of fuel and is not an estimate for the direct repercussions to Oregon consumers. The amount of fuel lost does not take into consideration the amount of time that the CEI Hub will be damaged and out of service, nor the availability of fuel from other storage areas.

\section{Conclusion}

This analysis provides insight into the CEI Hub's Tank damage probability through the use of existing Fragility Curves. Hazus, ALA, and D'Amico fragility curves used to determine possible damage outcomes. The probability ranged from $3.0-56 \%, 0.95-33 \%$, and $0.30 \%-15 \%$ for DS 3,4 , and 5 respectively. The range accounts for different fragility curves and PGA values of $0.187 \mathrm{~g}$ and $0.275 \mathrm{~g}$. The effects of percent fill and anchorage conditions were taken into account. The effects of percent fill for D'Amico caused the highest impact on in probability of damage. This analysis focused on damage due to ground acceleration, and future analysis should include possibility of liquefaction and fire damage. In addition, data on secondary containment, tank anchorage conditions, and average fill data should be used to create a more informed analysis. 


\section{References}

American Lifeline Alliance. (2001). Seismic Fragility Formulation for Water Systems - Part 1: Guidelines, rep., American Society of Civil Engineers.

American Lifeline Alliance. (2001). Seismic Fragility Formulation for Water Systems - Part 2: Appendices, rep., American Society of Civil Engineers.

D'Amico, M., and Buratti, N. (2018). “Observational Seismic Fragility Curves for Steel Cylindrical Tanks.” Journal of Pressure Vessel Technology, 141(1).

Dusicka, P. (n.d.). CSZ@PDX, Portland State University, $<$ https: $/ / \mathrm{m} 9$ csz.cee.pdx.edu $/ \mathrm{m} 9 \mathrm{csz} /$ ?field $=$ spectra5_x\&zone $=$ B\&realization $=$ mean\&time $=0$ $.2 \&$ lines $=>$ (Accessed 18 May 2021).

Dusicka, P., and Norton, G. (2019). Liquid Storage Tanks at the Critical Energy Infrastructure (CEI) Hub Seismic Assessment of Tank Inventory, rep.

Environmental Protection Agency. Spill Prevention, Control, and Countermeasure (SPCC) Regulation. (2021).

Federal Emergency Management Agency. (2020). Hazus Earthquake Model Technical Manual.

Frankel, A., Wirth, E., Marafi, N., Vidale, J., and Stephenson, W. (2018). "Broadband Synthetic Seismograms for Magnitude 9 Earthquakes on the Cascadia Megathrust Based on 3D Simulations and Stochastic Synthetics, Part 1: Methodology and Overall Results." Bulletin of the Seismological Society of America, 108(5A), 2347-2369.

Office of Economic Analysis. (2019). 2019 Fuel Supply Forecast, State of Oregon.

Wirth, E. A., Frankel, A. D., Marafi, N., Vidale, J. E., and Stephenson, W. J. (2018). "Broadband Synthetic Seismograms for Magnitude 9 Earthquakes on the Cascadia Megathrust Based on 3D Simulations and Stochastic Synthetics, Part 2: Rupture Parameters and Variability." Bulletin of the Seismological Society of America, 108(5A), 2370-2388. 


\section{Appendix A - Secondary Containment}
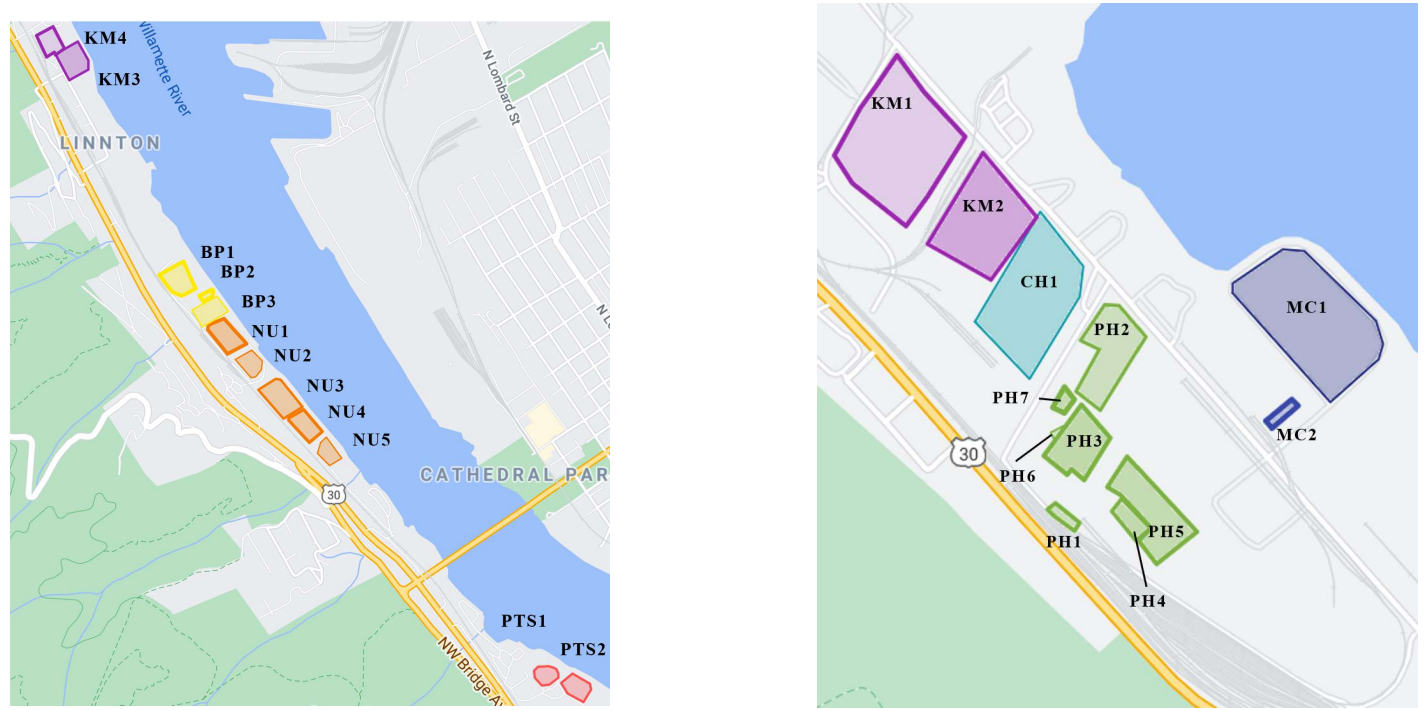

Figure A-1 (Left) Northern secondary containment areas. (Right) Southern secondary containment areas.

Table A-1 Total area, number of tanks, and total capacity of secondary containment areas. Number of tanks and total capacity do not take into account the 100,000 gallon capacity cut-off.

\begin{tabular}{|l|r|r|r|}
\hline SC & Area (acres) & Number of Tanks & Total Capacity (gal) \\
\hline BP1 & 2.9 & 11 & 13640110 \\
\hline BP2 & 0.355 & 7 & 221970 \\
\hline BP3 & 2.42 & 8 & 10084158 \\
\hline KM1 & 10.1 & 28 & 39279634 \\
\hline KM2 & 6.05 & 44 & 32582087 \\
\hline KM3 & 3.11 & 10 & 11900238 \\
\hline KM4 & 1.97 & 4 & 7881877 \\
\hline NU1 & 2.91 & 8 & 10985710 \\
\hline NU2 & 1.8 & 6 & 8252706 \\
\hline NU3 & 3.6 & 4 & 12457926 \\
\hline NU4 & 2.26 & 11 & 13483039 \\
\hline NU5 & 1.49 & 2 & 8400000 \\
\hline PH1 & 0.294 & 38 & 610100 \\
\hline PH2 & 3.29 & 12 & 12461194 \\
\hline PH3 & 2.21 & 10 & 5375772 \\
\hline PH4 & 0.592 & 3 & 1369242 \\
\hline PH5 & 3.14 & 21 & 9701866 \\
\hline PH6 & 0.066 & 1 & 20496 \\
\hline PH7 & 0.249 & 2 & 36876 \\
\hline PTS1 & 1.51 & 3 & 140000 \\
\hline PTS2 & 2.07 & 2 & 135000 \\
\hline CH1 & 8.05 & 28 & 47923305 \\
\hline MC1 & 10.7 & 11 & 38758692 \\
\hline MC2 & 0.262 & 3 & 1283604 \\
\hline
\end{tabular}




\section{Appendix B - Fragility Curves}

Table B-1 Hazus lognormal parameters for fragility curves

(Federal Emergency Management Agency, 2020)..

\begin{tabular}{|l|r|r|r|r|}
\hline \multirow{2}{*}{$\begin{array}{c}\text { Fragility } \\
\text { Parameters }\end{array}$} & \multicolumn{5}{|c|}{ Damage State } \\
\cline { 2 - 5 } & DS $>=2$ & DS $>=3$ & DS $>=4$ & DS $=5$ \\
\hline Anchored \\
\hline $\mathrm{m}(\mathrm{g})$ & 0.29 & 0.5 & 0.5 & 0.87 \\
\hline$\mu(\ln (\mathrm{g}))$ & -0.5376 & -0.30103 & -0.30103 & -0.06048 \\
\hline$\sigma(\ln (\mathrm{g}))$ & 0.55 & 0.55 & 0.55 & 0.5 \\
\hline Unanchored \\
\hline $\mathrm{m}(\mathrm{g})$ & 0.12 & 0.23 & 0.41 & 0.68 \\
\hline$\mu(\ln (\mathrm{g}))$ & -0.92082 & -0.63827 & -0.38722 & -0.16749 \\
\hline$\sigma(\ln (\mathrm{g}))$ & 0.55 & 0.55 & 0.55 & 0.55 \\
\hline
\end{tabular}


Table B-2 ALA lognormal fragility curve parameters

(American Lifeline Alliance, 2001)

\begin{tabular}{|l|r|r|r|r|}
\hline \multirow{4}{*}{$\begin{array}{c}\text { Fragility } \\
\text { Parameters }\end{array}$} & \multicolumn{5}{|c|}{ Damage Stress } \\
\cline { 2 - 5 } & $\mathrm{DS}>=2$ & $\mathrm{DS}>=3$ & $\mathrm{DS}>=4$ & $\mathrm{DS}=5$ \\
\hline All Tanks \\
\hline $\mathrm{m}(\mathrm{g})$ & 0.38 & 0.86 & 1.18 & 1.16 \\
\hline$\mu(\ln (\mathrm{g}))$ & -0.97 & -0.15 & 0.17 & 0.15 \\
\hline$\sigma(\ln (\mathrm{g}))$ & 0.8 & 0.8 & 0.61 & 0.07 \\
\hline
\end{tabular}

FL $<50 \%$

\begin{tabular}{|l|r|r|r|r|}
\hline $\mathrm{m}(\mathrm{g})$ & 0.56 & $>2.00$ & - & - \\
\hline$\mu(\ln (\mathrm{g}))$ & -0.58 & - & - & - \\
\hline$\sigma(\ln (\mathrm{g}))$ & 0.8 & 0.4 & - & - \\
\hline $\mathrm{FL}>=50 \%$ & \\
\hline $\mathrm{m}(\mathrm{g})$ & 0.18 & 0.73 & 1.14 & 1.16 \\
\hline$\mu(\ln (\mathrm{g}))$ & -1.71 & -0.31 & 0.13 & 0.15 \\
\hline$\sigma(\ln (\mathrm{g}))$ & 0.8 & 0.8 & 0.8 & 0.4 \\
\hline
\end{tabular}

FL $>=60 \%$

\begin{tabular}{|l|r|r|r|r|}
\hline $\mathrm{m}(\mathrm{g})$ & 0.22 & 0.7 & 1.09 & 1.16 \\
\hline$\mu(\ln (\mathrm{g}))$ & -1.51 & -0.36 & 0.09 & 0.15 \\
\hline$\sigma(\ln (\mathrm{g}))$ & 0.8 & 0.8 & 0.8 & 0.41 \\
\hline
\end{tabular}

FL $>=90 \%$

\begin{tabular}{|l|r|r|r|r|}
\hline $\mathrm{m}(\mathrm{g})$ & 0.13 & 0.67 & 1.01 & 1.15 \\
\hline$\mu(\ln (\mathrm{g}))$ & -2.04 & -0.4 & 0.01 & 0.14 \\
\hline$\sigma(\ln (\mathrm{g}))$ & 0.07 & 0.8 & 0.8 & 0.1 \\
\hline
\end{tabular}

FL $>=50 \%$ Anchored

\begin{tabular}{|l|r|r|r|r|}
\hline $\mathrm{m}(\mathrm{g})$ & 0.71 & 2.36 & 3.72 & 4.26 \\
\hline$\mu(\ln (\mathrm{g}))$ & -0.34 & 0.86 & 1.31 & 1.45 \\
\hline$\sigma(\ln (\mathrm{g}))$ & 0.8 & 0.8 & 0.8 & 0.8 \\
\hline
\end{tabular}

FL $>=50 \%$ Unanchored

\begin{tabular}{|l|r|r|r|r|}
\hline $\mathrm{m}(\mathrm{g})$ & 0.15 & 0.62 & 1.06 & 1.13 \\
\hline$\mu(\ln (\mathrm{g}))$ & -1.9 & -0.48 & 0.06 & 0.12 \\
\hline$\sigma(\ln (\mathrm{g}))$ & 0.12 & 0.8 & 0.8 & 0.1 \\
\hline
\end{tabular}


Table B-3 D'Amico lognormal fragility curve parameters

(D'Amico \& Buratti, 2018).

\begin{tabular}{|c|c|c|c|c|}
\hline \multirow{2}{*}{$\begin{array}{l}\text { Fragility } \\
\text { Parameters }\end{array}$} & \multicolumn{4}{|c|}{ Damage States } \\
\hline & $\mathrm{DS}=2$ & $\mathrm{DS}>=3$ & $\mathrm{DS}>=4$ & $\mathrm{DS}=5$ \\
\hline \multicolumn{5}{|c|}{$\mathrm{FL}=0.2$} \\
\hline$\mu(\ln (g))$ & 14.317 & 0.526 & 1.241 & 3.512 \\
\hline$\sigma(\ln (\mathrm{g}))$ & 7.795 & 1.256 & 1.457 & 1.96 \\
\hline \multicolumn{5}{|l|}{$\mathrm{FL}=0.5$} \\
\hline$\mu(\ln (\mathrm{g}))$ & 10.256 & -0.104 & 0.549 & 2.311 \\
\hline$\sigma(\ln (g))$ & 7.795 & 1.256 & 1.457 & 1.96 \\
\hline \multicolumn{5}{|l|}{$\mathrm{FL}=0.9$} \\
\hline$\mu(\ln (g))$ & 4.84 & -0.943 & -0.373 & 0.71 \\
\hline$\sigma(\ln (g))$ & 7.795 & 1.256 & 1.457 & 1.96 \\
\hline \multicolumn{5}{|l|}{ Unanchored } \\
\hline$\mu(\ln (g))$ & 1.69 & -0.563 & -0.049 & 0.488 \\
\hline$\sigma(\ln (\mathrm{g}))$ & 2.243 & 1.02 & 1.096 & 1.128 \\
\hline \multicolumn{5}{|l|}{ All Tanks } \\
\hline$\mu(\ln (g))$ & 1.967 & 0.109 & 0.281 & 0.862 \\
\hline$\sigma(\ln (g))$ & 1.899 & 0.951 & 1.05 & 1.13 \\
\hline
\end{tabular}
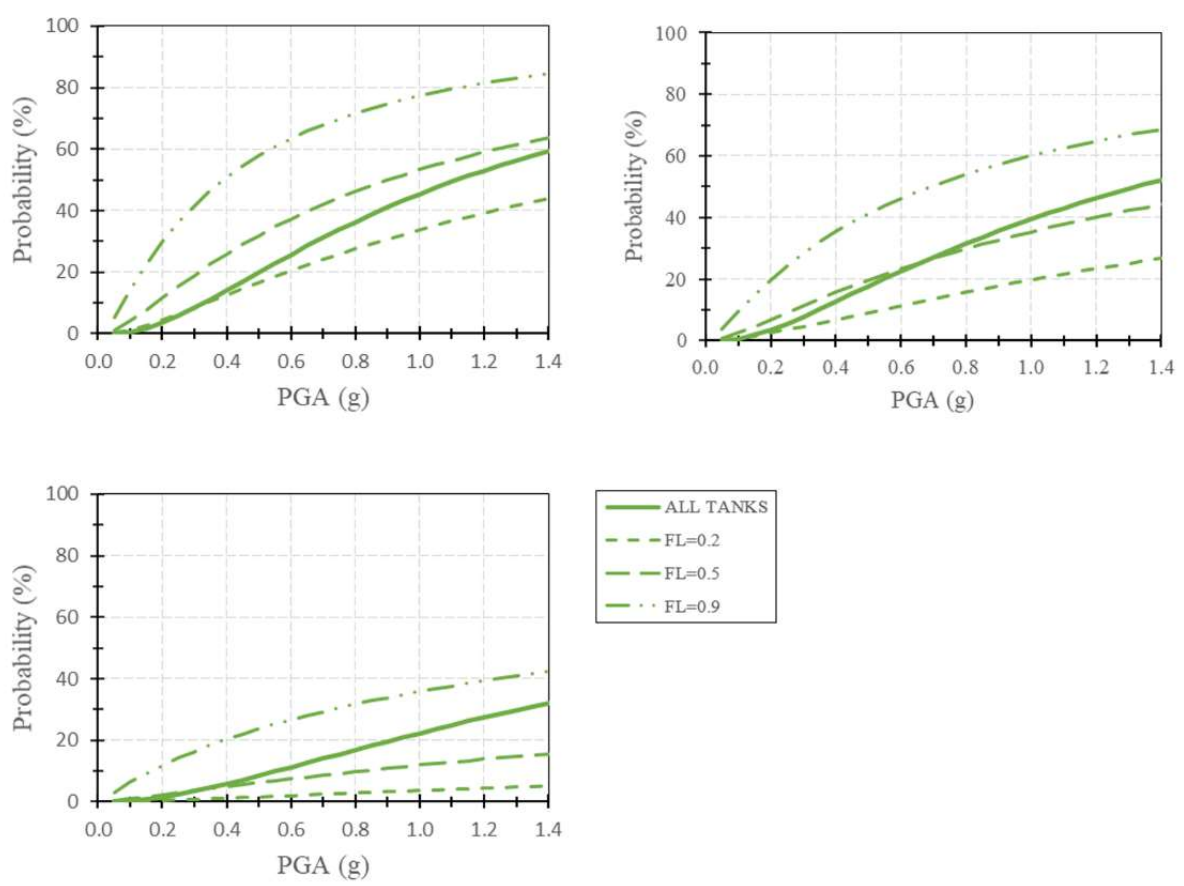

Figure B-1 D'Amico percent fill fragility curves. (Top Right) DS 3. (Top Left) DS 4. (Bottom Right) DS 5 . 

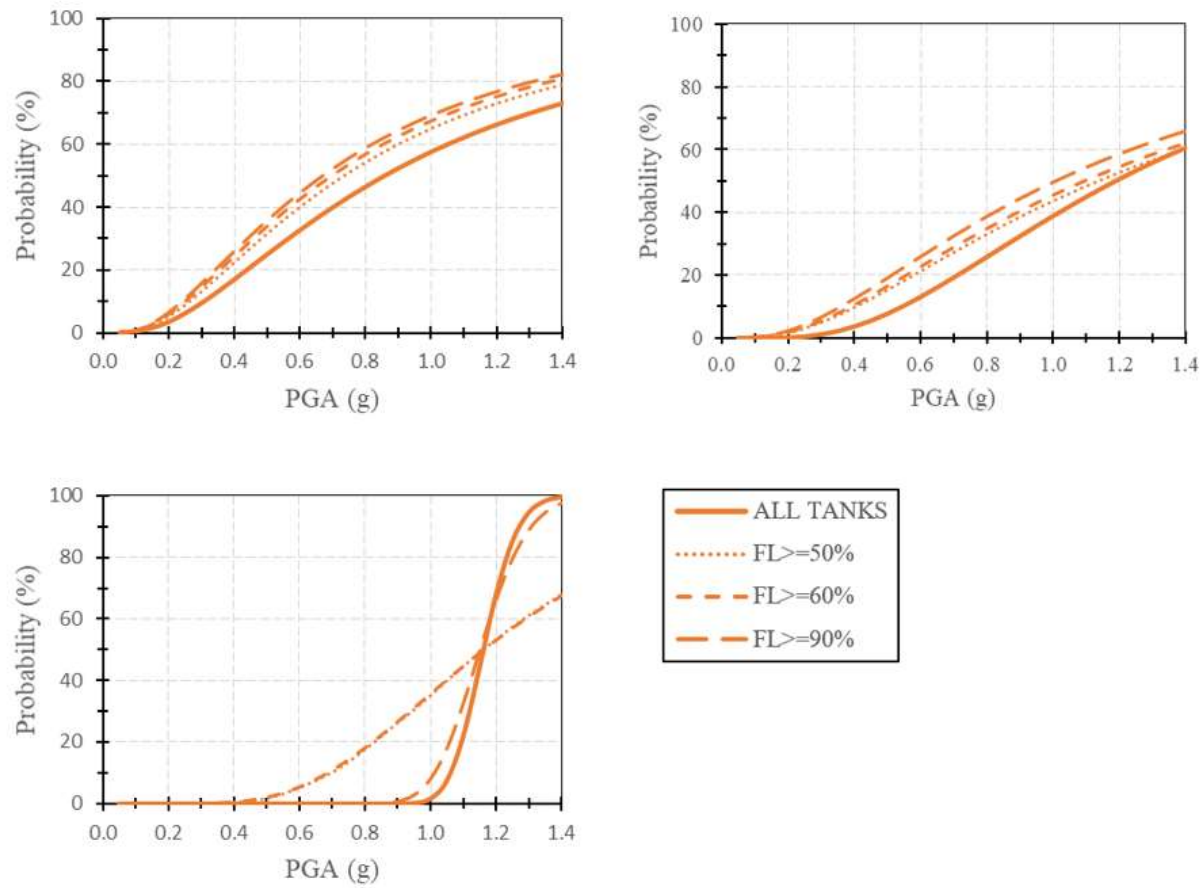

$$
\begin{aligned}
& \text { ALL TANKS } \\
& \ldots \ldots . . . \text { FL }>=50 \% \\
& --- \text { FL }>=60 \% \\
& -- \text { FL }>=90 \%
\end{aligned}
$$

Figure B-2 ALA percent fill fragility curves. (Top Right) DS 3. (Top Left) DS 4. (Bottom Right) DS 5.
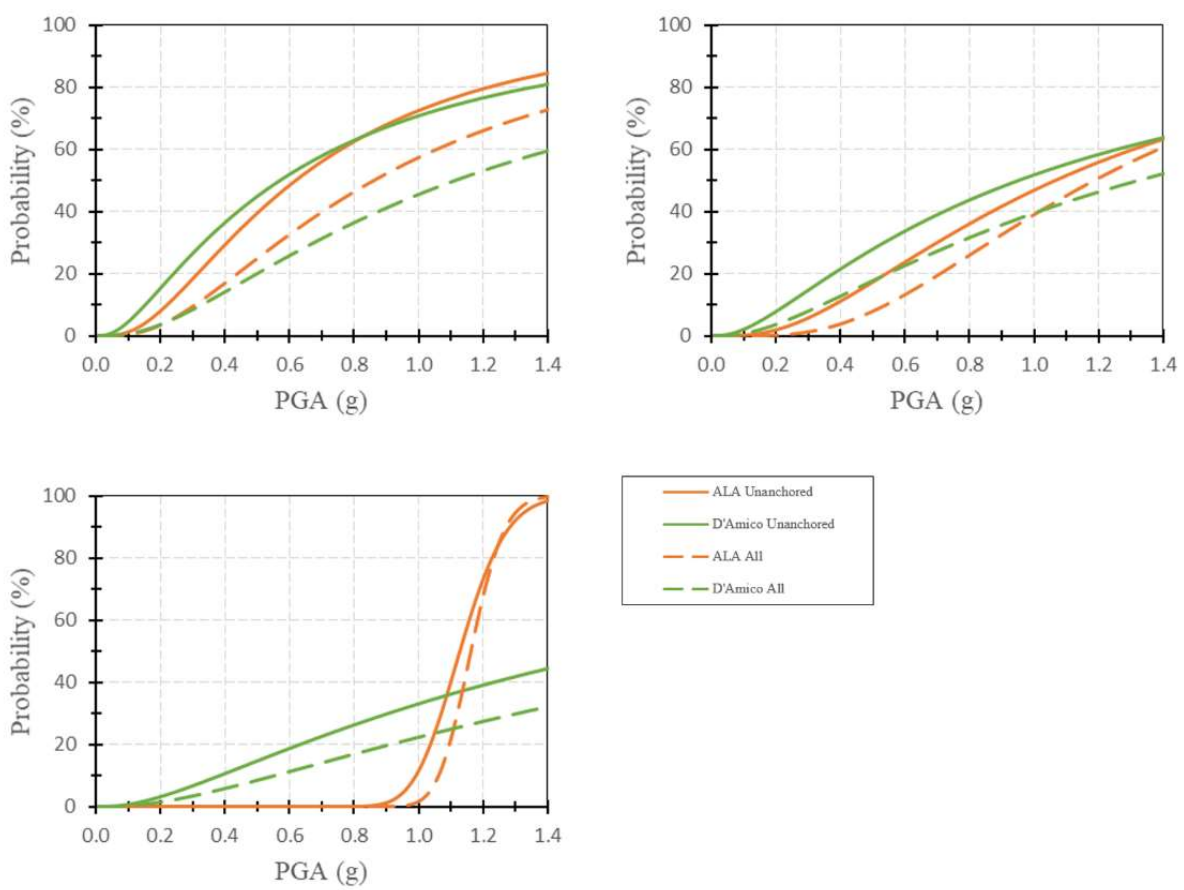

Figure B-3 D'Amico and ALA unanchored tanks versus all tanks fragility curves. (Top Right) DS 3. (Top Left) DS 4. (Bottom Right) DS 5 . 

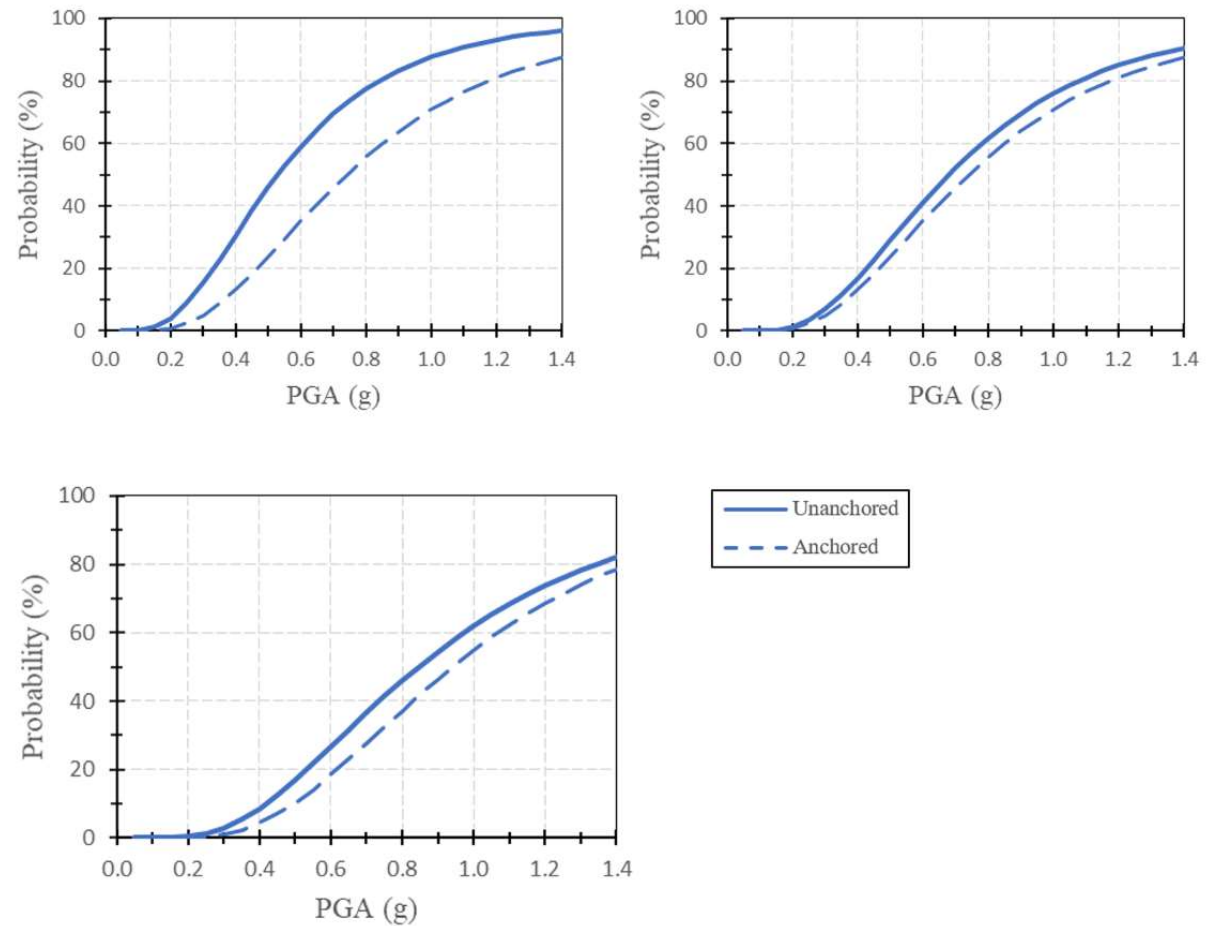

Figure B-4 Hazus unanchored tanks verus anchored tanks fragility curves. (Top Right) DS 3. (Top Left) DS 4. (Bottom Right) DS 5 .
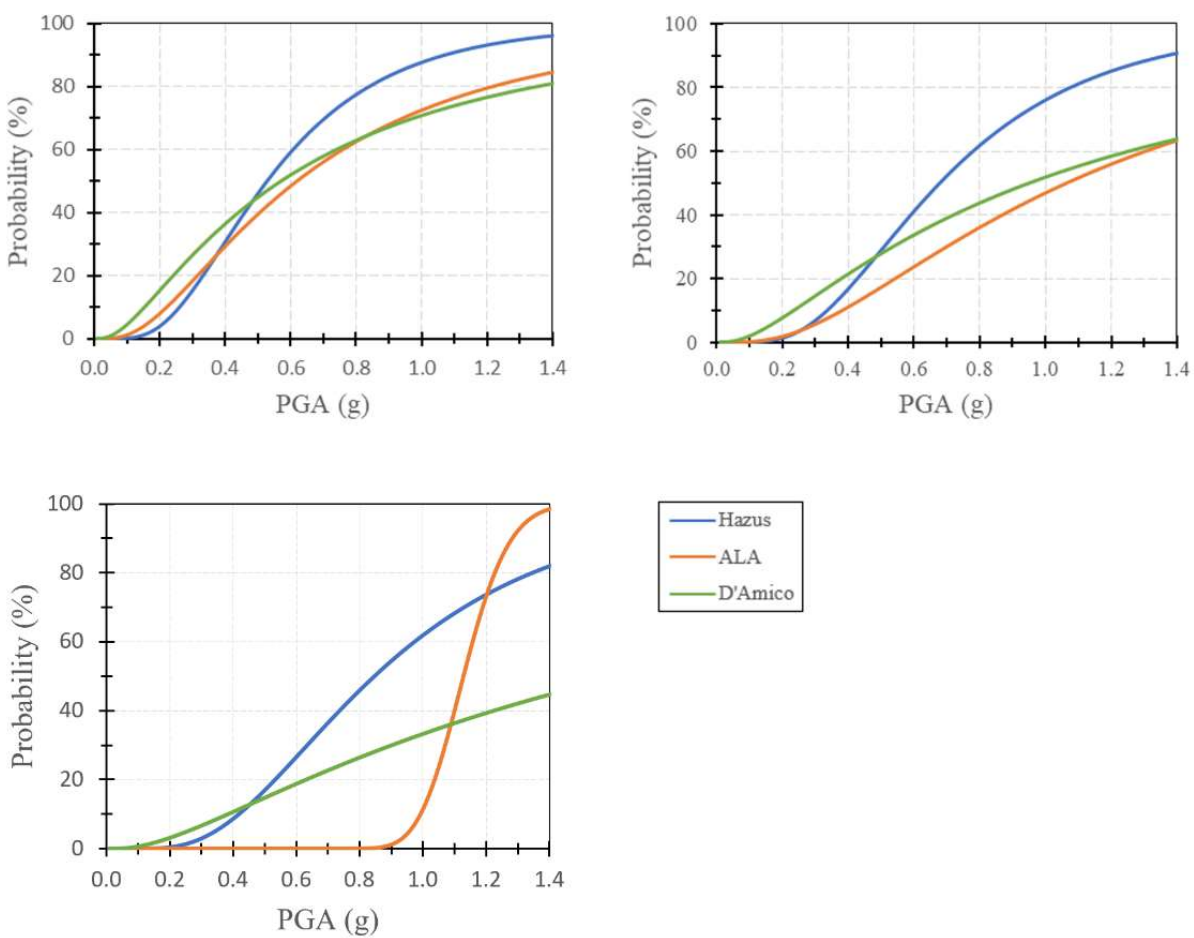

Figure B-5 Hazus, ALA, and D'Amico unanchored tanks fragility curves. (Top Right) DS 3. (Top Left) DS 4. (Bottom Right) DS 5 . 

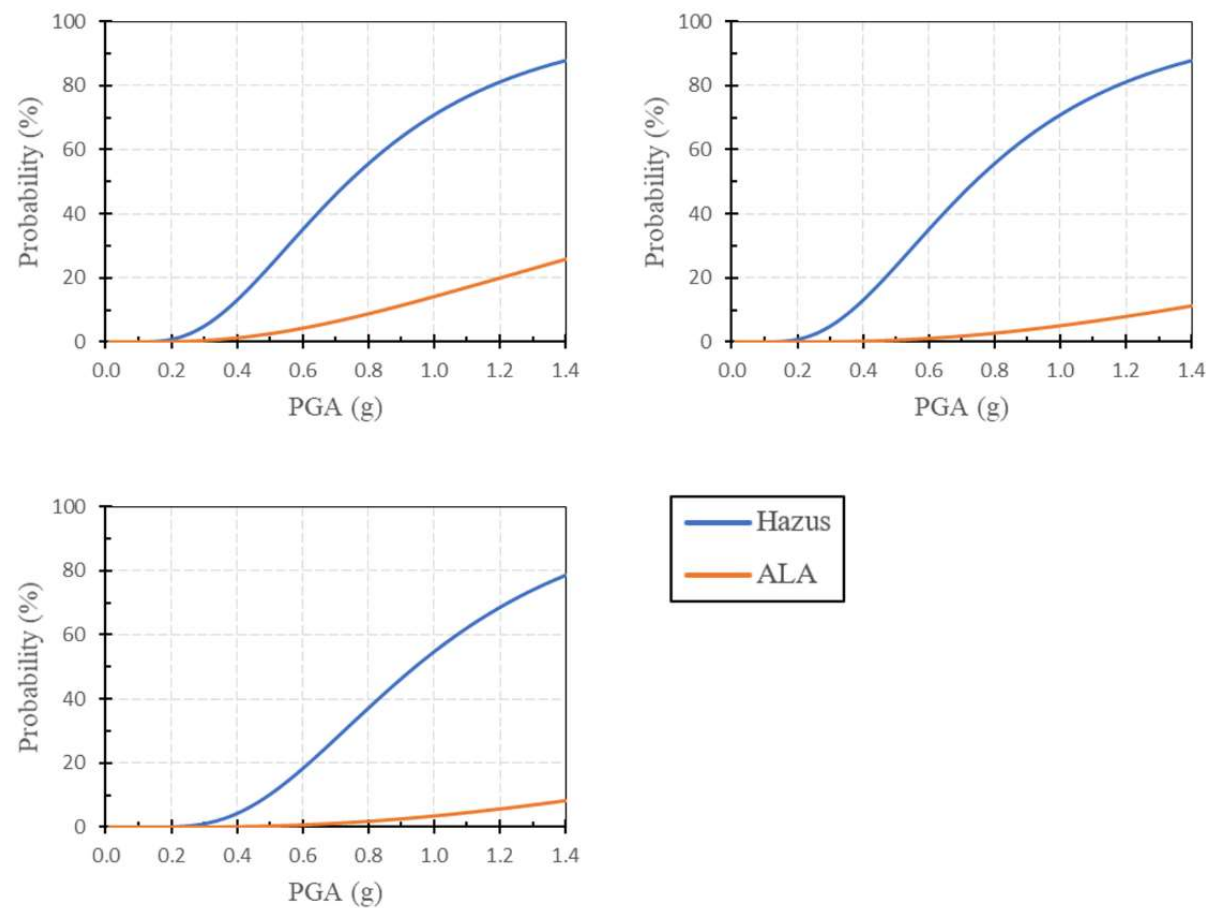

Figure B-6 Hazus and ALA anchored tanks fragility curves. (Top Right) DS 3. (Top Left) DS 4. (Bottom Right) DS 5 .
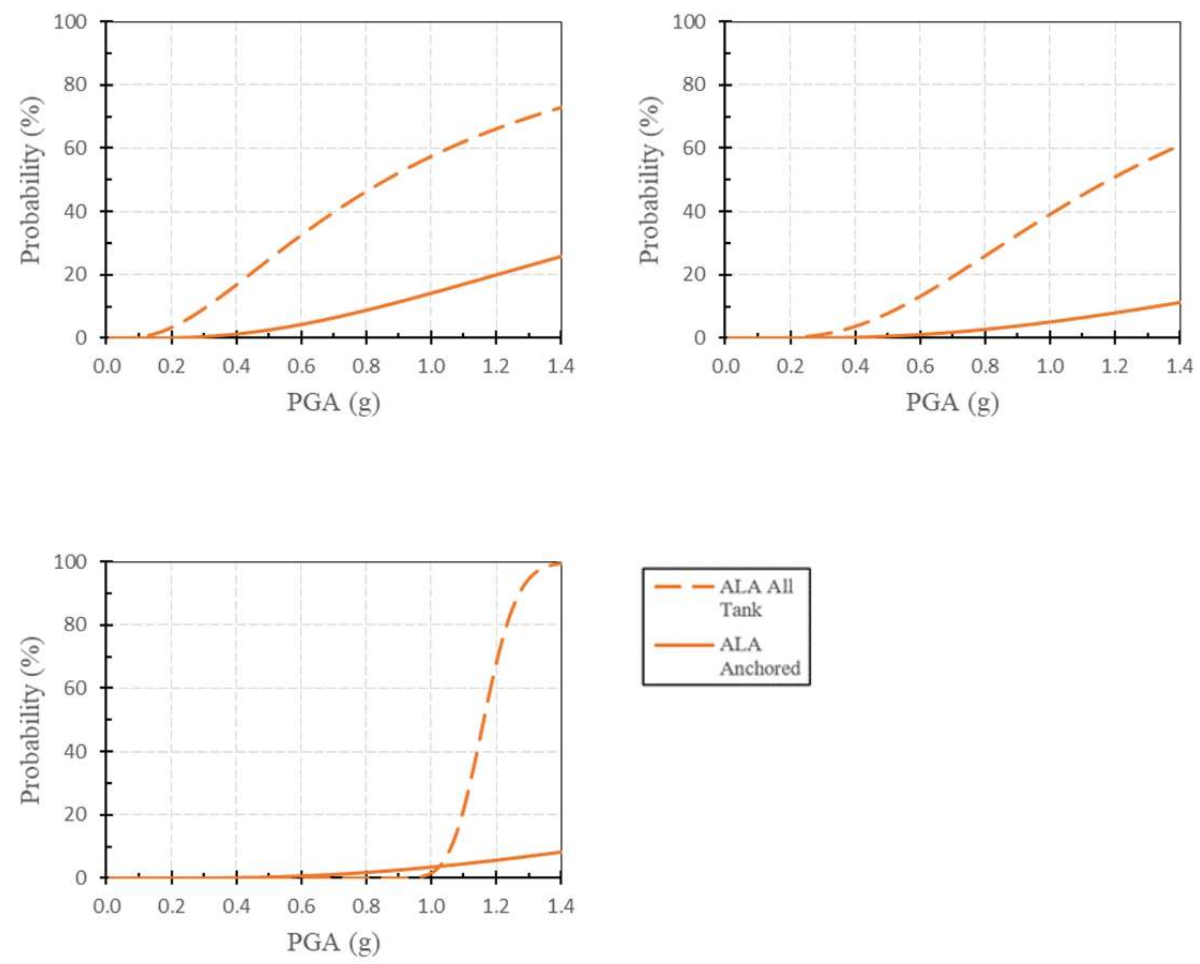

Figure B-7 ALA anchored tanks verus all tanks fragility curves. (Top Right) DS 3. (Top Left) DS 4. (Bottom Right) DS 5 . 


\section{Appendix C - Analysis}

Table C-1 Probability of damage, expected number of tanks and content affected for the mean and mean plus one standard deviation PGA values.

\begin{tabular}{|c|c|c|c|c|c|c|}
\hline Parameter & $\mu$ & $\begin{array}{l}\text { Damage } \mu \\
\text { Number of Tanks }\end{array}$ & $\begin{array}{l}\text { Damage } \mu \text { Content } \\
\text { (million gal) }\end{array}$ & $\mu+\sigma$ & $\begin{array}{l}\text { Damage } \mu+\sigma \\
\text { Number of Tanks }\end{array}$ & \begin{tabular}{|l} 
Damage $\mu+\sigma$ Content \\
(million gal)
\end{tabular} \\
\hline PGA (g) & 0.187 & 0.187 & 0.187 & 0.275 & 0.275 & 0.275 \\
\hline \multicolumn{7}{|c|}{ DS3 } \\
\hline HAZUS Unachored & 2.95 & 5.81 & 8.40 & 11.77 & 23.18 & 33.49 \\
\hline ALA Unanchored & 6.74 & 13.27 & 19.17 & 15.54 & 30.61 & 44.22 \\
\hline D'Amico Unanchored & 13.75 & 27.08 & 39.13 & 23.77 & 46.83 & 67.66 \\
\hline ALA Scaled & 7.88 & 15.53 & 22.44 & 17.80 & 35.07 & 50.66 \\
\hline D'Amico Scaled & 38.68 & 76.20 & 110.10 & 55.81 & 109.94 & 158.85 \\
\hline \multicolumn{7}{|c|}{ DS4 } \\
\hline HAZUS Unachored & 0.95 & 1.88 & 2.71 & 5.02 & 9.88 & 14.28 \\
\hline ALA Unanchored & 1.50 & 2.95 & 4.26 & 4.56 & 8.99 & 12.99 \\
\hline D'Amico Unanchored & 6.88 & 13.55 & 19.57 & 12.86 & 25.33 & 36.59 \\
\hline ALA Scaled & 2.05 & 4.04 & 5.84 & 5.97 & 11.77 & 17.00 \\
\hline D'Amico Scaled & 22.31 & 43.95 & 63.50 & 32.57 & 64.17 & 92.71 \\
\hline \multicolumn{7}{|c|}{ DS5 } \\
\hline HAZUS Unachored & 0.30 & 0.60 & 0.86 & 2.05 & 4.05 & 5.85 \\
\hline ALA Unanchored & 0.00 & 0.00 & $5.08 \mathrm{E}-70$ & 0.00 & 0.00 & $4.70 \mathrm{E}-43$ \\
\hline D'Amico Unanchored & 2.75 & 5.42 & 7.83 & 2.84 & 5.59 & 8.08 \\
\hline D'Amico Scaled & 12.68 & 24.99 & 36.10 & 15.36 & 30.27 & 43.73 \\
\hline
\end{tabular}

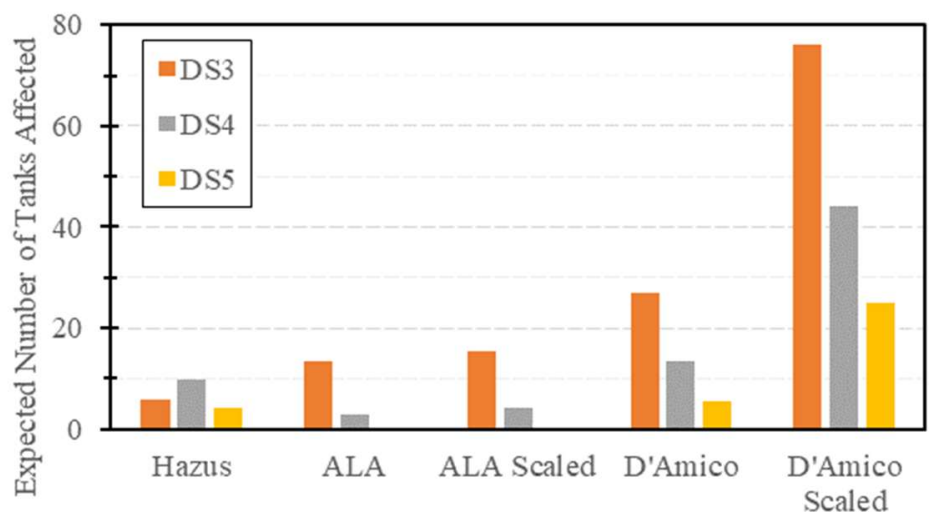

Fragility Curve

Figure C-1 Expected number of tanks affected by the mean $P G A$ value $(0.187 \mathrm{~g})$. 


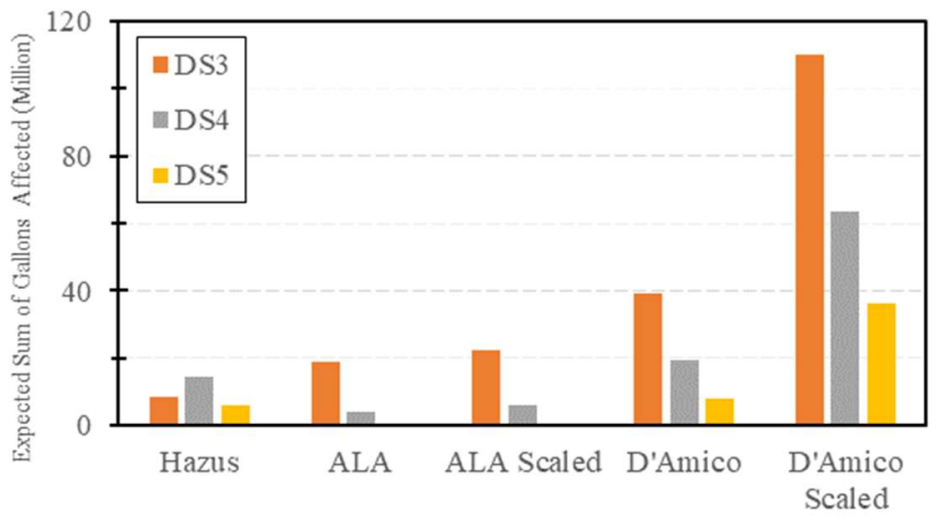

Fragility Curve

Figure C-2 Expected number of gallons affected by the mean $P G A$ value (0.187g).

Table C-2 Expected fuel repercussions for each fragility estimation for a (Top) PGA value of $0.275 \mathrm{~g}$ and (Bottom) PGA value of $0.187 \mathrm{~g}$.

\begin{tabular}{|c|c|c|c|c|c|c|c|c|c|c|c|c|c|c|c|}
\hline & \multicolumn{3}{|c|}{ Hazus Estimate (Gallons) } & \multicolumn{3}{|c|}{ ALA Estimate (Gallons) } & \multicolumn{3}{|c|}{ D'Amico Estimate (Gallons) } & \multicolumn{3}{|c|}{ ALA Scaled Estimate (Gallons) } & \multicolumn{3}{|c|}{ D'Amico Scaled Estimate (Gallons) } \\
\hline Fuel & DS3 & \begin{tabular}{l|l} 
DS4 \\
\end{tabular} & 2 DS5 & \begin{tabular}{l|l} 
DS3 \\
\end{tabular} & \begin{tabular}{l|l} 
DS4 \\
\end{tabular} & $\begin{array}{c}\text { DS5 } \\
\end{array}$ & \begin{tabular}{l|l} 
DS3 \\
\end{tabular} & \begin{tabular}{l|l} 
DS4 \\
\end{tabular} & DS5 & DS3 & DS4 & DS5 & \begin{tabular}{|l|} 
DS3 \\
\end{tabular} & DS4 & DS5 \\
\hline Diesel & $7.29 \mathrm{E}+06$ & $3.11 \mathrm{E}+06$ & $1.27 \mathrm{E}+06$ & $1.47 \mathrm{E}+07$ & $2.83 \mathrm{E}+06$ & $1.02 \mathrm{E}-37$ & $1.47 \mathrm{E}+07$ & $7.97 \mathrm{E}+06$ & $1.76 \mathrm{E}+06$ & $1.10 \mathrm{E}+07$ & $3.70 \mathrm{E}+06$ & $1.02 \mathrm{E}-37$ & $3.46 \mathrm{E}+07$ & $2.02 \mathrm{E}+07$ & $9.52 \mathrm{E}+06$ \\
\hline Ethanol & $9.35 \mathrm{E}+05$ & $3.99 \mathrm{E}+05$ & $1.63 \mathrm{E}+05$ & $1.89 \mathrm{E}+06$ & $3.63 \mathrm{E}+05$ & $1.31 \mathrm{IE}-38$ & $1.89 \mathrm{E}+06$ & $1.02 \mathrm{E}+06$ & $2.25 \mathrm{E}+05$ & $1.41 \mathrm{E}+06$ & $4.75 \mathrm{E}+05$ & $1.31 \mathrm{E}-38$ & $4.44 \mathrm{E}+06$ & $2.59 \mathrm{E}+06$ & $1.22 \mathrm{E}+06$ \\
\hline Gasoline & $1.05 \mathrm{E}+07$ & $4.47 \mathrm{E}+06$ & $1.83 \mathrm{E}+06$ & $2.12 \mathrm{E}+07$ & $4.06 \mathrm{E}+06$ & $1.47 \mathrm{E}-37$ & $2.12 \mathrm{E}+07$ & $1.14 \mathrm{E}+07$ & $2.53 \mathrm{E}+06$ & $1.58 \mathrm{E}+07$ & $5.32 \mathrm{E}+06$ & $1.47 \mathrm{E}-37$ & $4.97 \mathrm{E}+07$ & $2.90 \mathrm{E}+07$ & $1.37 \mathrm{E}+07$ \\
\hline Gasoline/Diesel & $3.29 \mathrm{E}+06$ & $1.40 \mathrm{E}+06$ & $5.74 \mathrm{E}+05$ & $6.64 \mathrm{E}+06$ & $1.27 \mathrm{E}+06$ & $4.61 \mathrm{E}-38$ & $6.64 \mathrm{E}+06$ & $3.59 \mathrm{E}+06$ & $7.92 \mathrm{E}+05$ & $4.97 \mathrm{E}+06$ & $1.67 \mathrm{E}+06$ & $4.61 \mathrm{E}-38$ & $1.56 \mathrm{E}+07$ & $9.10 \mathrm{E}+06$ & $4.29 \mathrm{E}+06$ \\
\hline Jet Fuel & $2.21 \mathrm{E}+06$ & $9.42 \mathrm{E}+05$ & $3.86 \mathrm{E}+05$ & $4.46 \mathrm{E}+06$ & $8.57 \mathrm{E}+05$ & $3.10 \mathrm{E}-38$ & $4.46 \mathrm{E}+06$ & $2.41 \mathrm{E}+06$ & $5.33 \mathrm{E}+05$ & $3.34 \mathrm{E}+06$ & $1.12 \mathrm{E}+06$ & $3.10 \mathrm{E}-38$ & $1.05 \mathrm{E}+07$ & $6.12 \mathrm{E}+06$ & $2.88 \mathrm{E}+06$ \\
\hline Non-fuel & $5.93 \mathrm{E}+06$ & $2.53 \mathrm{E}+06$ & $1.03 \mathrm{E}+06$ & $1.20 \mathrm{E}+07$ & $2.30 \mathrm{E}+06$ & $8.32 \mathrm{E}-38$ & $1.20 \mathrm{E}+07$ & $6.48 \mathrm{E}+06$ & $1.43 \mathrm{E}+06$ & $8.97 \mathrm{E}+06$ & $3.01 \mathrm{E}+06$ & $8.32 \mathrm{E}-38$ & $2.81 \mathrm{E}+07$ & $1.64 \mathrm{E}+07$ & $7.74 \mathrm{E}+06$ \\
\hline Out of Service & $1.87 \mathrm{E}+06$ & $7.98 \mathrm{E}+05$ & $3.27 \mathrm{E}+05$ & $3.78 \mathrm{E}+06$ & $7.26 \mathrm{E}+05$ & $2.63 \mathrm{E}-38$ & $3.78 \mathrm{E}+06$ & $2.05 \mathrm{E}+06$ & $4.51 \mathrm{E}+05$ & $2.83 \mathrm{E}+06$ & $9.50 \mathrm{E}+05$ & $2.63 \mathrm{E}-38$ & $8.88 \mathrm{E}+06$ & $5.18 \mathrm{E}+06$ & $2.44 \mathrm{E}+06$ \\
\hline Unknown & $1.50 \mathrm{E}+06$ & $6.38 \mathrm{E}+05$ & $2.61 \mathrm{E}+05$ & $3.02 \mathrm{E}+06$ & $5.80 \mathrm{E}+05$ & $2.10 \mathrm{E}-38$ & $3.02 \mathrm{E}+06$ & $1.63 \mathrm{E}+06$ & $3.61 \mathrm{E}+05$ & $2.26 \mathrm{E}+06$ & $7.59 \mathrm{E}+05$ & $2.10 \mathrm{E}-38$ & $7.09 \mathrm{E}+06$ & $4.14 \mathrm{E}+06$ & $1.95 \mathrm{E}+06$ \\
\hline
\end{tabular}

\begin{tabular}{|c|c|c|c|c|c|c|c|c|c|c|c|c|c|c|c|}
\hline & \multicolumn{3}{|c|}{ Hazus Estimate (Gallons) } & \multicolumn{3}{|c|}{ ALA Estimate (Gallons) } & \multicolumn{3}{|c|}{ D'Amico Estimate (Gallons) } & \multicolumn{3}{|c|}{ ALA Scaled Estimate (Gallons) } & \multicolumn{3}{|c|}{ D'Amico Scaled Estimate (Gallons) } \\
\hline Fuel & DS3 & DS4 & DS5 & \begin{tabular}{l|l} 
DS3 & -1 \\
\end{tabular} & DS4 & DS5 & DS3 & DS4 & DS5 & DS3 & DS4 & DS5 & \begin{tabular}{l|l} 
DS3 & \\
\end{tabular} & DS4 & DS5 \\
\hline Diesel & $1.83 \mathrm{E}+06$ & $5.90 \mathrm{E}+05$ & $1.88 \mathrm{E}+05$ & $8.52 \mathrm{E}+06$ & $9.28 \mathrm{E}+05$ & $1.11 \mathrm{E}-64$ & $8.52 \mathrm{E}+06$ & $4.26 \mathrm{E}+06$ & $1.70 \mathrm{E}+06$ & $4.88 \mathrm{E}+06$ & $1.27 \mathrm{E}+06$ & $1.11 \mathrm{E}-64$ & $2.40 \mathrm{E}+07$ & $1.38 \mathrm{E}+07$ & $7.86 \mathrm{E}+06$ \\
\hline Ethanol & $2.35 \mathrm{E}+05$ & $7.57 \mathrm{E}+04$ & $2.41 \mathrm{E}+04$ & $1.09 \mathrm{E}+06$ & $1.19 \mathrm{E}+05$ & $1.42 \mathrm{E}-65$ & $1.09 \mathrm{E}+06$ & $5.47 \mathrm{E}+05$ & $2.19 \mathrm{E}+05$ & $6.27 \mathrm{E}+05$ & $1.63 \mathrm{E}+05$ & $1.42 \mathrm{E}-65$ & $3.07 \mathrm{E}+06$ & $1.77 \mathrm{E}+06$ & $1.01 \mathrm{E}+06$ \\
\hline Gasoline & $2.63 \mathrm{E}+06$ & $8.48 \mathrm{E}+05$ & $2.70 \mathrm{E}+05$ & $1.22 \mathrm{E}+07$ & $1.33 \mathrm{E}+06$ & $1.59 \mathrm{E}-64$ & $1.22 \mathrm{E}+07$ & $6.12 \mathrm{E}+06$ & $2.45 \mathrm{E}+06$ & $7.02 \mathrm{E}+06$ & $1.83 \mathrm{E}+06$ & $1.59 \mathrm{E}-64$ & $3.44 \mathrm{E}+07$ & $1.99 \mathrm{E}+07$ & $1.13 \mathrm{E}+07$ \\
\hline Gasoline/Diesel & $8.24 \mathrm{E}+05$ & $2.66 \mathrm{E}+05$ & $8.48 \mathrm{E}+04$ & $3.84 \mathrm{E}+06$ & $4.18 \mathrm{E}+05$ & $4.98 \mathrm{E}-65$ & $3.84 \mathrm{E}+06$ & $1.92 \mathrm{E}+06$ & $7.68 \mathrm{E}+05$ & $2.20 \mathrm{E}+06$ & $5.73 \mathrm{E}+05$ & $4.98 \mathrm{E}-65$ & $1.08 \mathrm{E}+07$ & $6.23 \mathrm{E}+06$ & $3.54 \mathrm{E}+06$ \\
\hline Jet Fuel & $5.54 \mathrm{E}+05$ & $1.79 \mathrm{E}+05$ & $5.70 \mathrm{E}+04$ & $2.58 \mathrm{E}+06$ & $2.81 \mathrm{E}+05$ & $3.35 \mathrm{E}-65$ & $2.58 \mathrm{E}+06$ & $1.29 \mathrm{E}+06$ & $5.16 \mathrm{E}+05$ & $1.48 \mathrm{E}+06$ & $3.85 \mathrm{E}+05$ & $3.35 \mathrm{E}-65$ & $7.26 \mathrm{E}+06$ & $4.19 \mathrm{E}+06$ & $2.38 \mathrm{E}+06$ \\
\hline Non-fuel & $1.49 \mathrm{E}+06$ & $4.80 \mathrm{E}+05$ & $1.53 \mathrm{E}+05$ & $6.92 \mathrm{E}+06$ & $7.54 \mathrm{E}+05$ & $8.98 \mathrm{E}-65$ & $6.92 \mathrm{E}+06$ & $3.46 \mathrm{E}+06$ & $1.38 \mathrm{E}+06$ & $3.97 \mathrm{E}+06$ & $1.03 \mathrm{E}+06$ & $8.98 \mathrm{E}-65$ & $1.95 \mathrm{E}+07$ & $1.12 \mathrm{E}+07$ & $6.39 \mathrm{E}+06$ \\
\hline Out of Service & $4.70 \mathrm{E}+05$ & $1.52 \mathrm{E}+05$ & $4.83 \mathrm{E}+04$ & $2.19 \mathrm{E}+06$ & $2.38 \mathrm{E}+05$ & $2.84 \mathrm{E}-65$ & $2.19 \mathrm{E}+06$ & $1.09 \mathrm{E}+06$ & $4.37 \mathrm{E}+05$ & $1.25 \mathrm{E}+06$ & $3.26 \mathrm{E}+05$ & $2.84 \mathrm{E}-65$ & $6.15 \mathrm{E}+06$ & $3.55 \mathrm{E}+06$ & $2.02 \mathrm{E}+06$ \\
\hline \begin{tabular}{|l|} 
Unknown \\
\end{tabular} & $3.75 \mathrm{E}+05$ & $1.21 \mathrm{E}+05$ & $3.86 \mathrm{E}+04$ & \begin{tabular}{|l|}
$1.75 \mathrm{E}+06$ \\
\end{tabular} & $1.90 \mathrm{E}+05$ & $2.27 \mathrm{E}-65$ & $1.75 \mathrm{E}+06$ & $8.74 \mathrm{E}+05$ & $3.49 \mathrm{E}+05$ & $1.00 \mathrm{E}+06$ & $2.61 \mathrm{E}+05$ & $2.27 \mathrm{E}-65$ & $4.92 \mathrm{E}+06$ & $2.84 \mathrm{E}+06$ & $1.61 \mathrm{E}+06$ \\
\hline
\end{tabular}

